\title{
In our own hands: SWAA-Ghana champions the female condom
}

\author{
Kathleen Cravero \\ Michelle Skaer \\ Population Council \\ Victoria Ebin \\ Martha Brady \\ Population Council
}

Follow this and additional works at: https://knowledgecommons.popcouncil.org/departments_sbsr-pgy

Part of the Demography, Population, and Ecology Commons, Family, Life Course, and Society Commons, Gender and Sexuality Commons, International Public Health Commons, Maternal and Child Health Commons, Obstetrics and Gynecology Commons, and the Women's Health Commons How does access to this work benefit you? Let us know!

\section{Recommended Citation}

Cravero, Kathleen, Michelle Skaer, Victoria Ebin, and Martha Brady. 2006. "In our own hands: SWAA-Ghana champions the female condom," Quality/Calidad/Qualité no. 17. New York: Population Council. 
In Our Own Hands:

SWAA-Ghana Champions the Female Condom
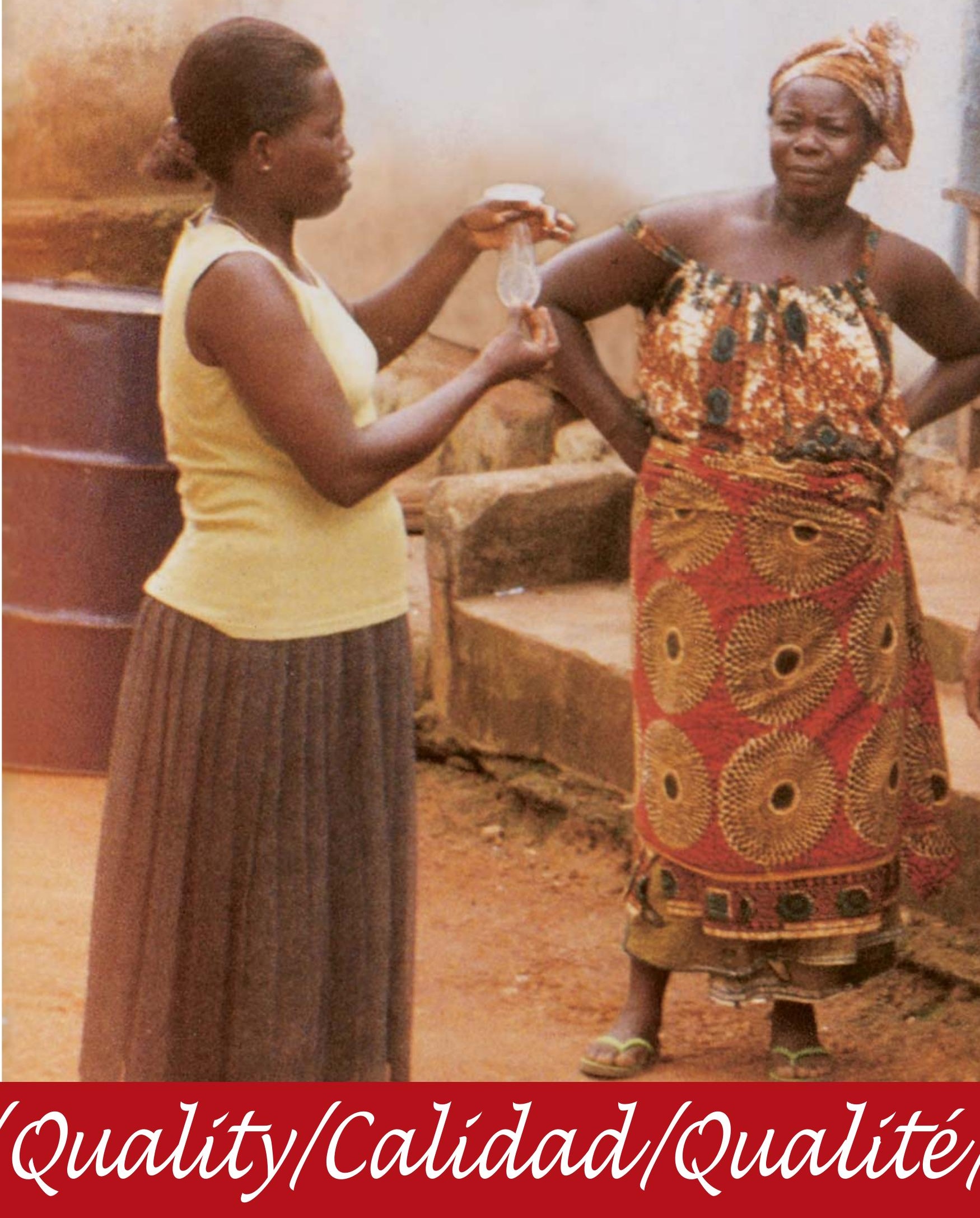


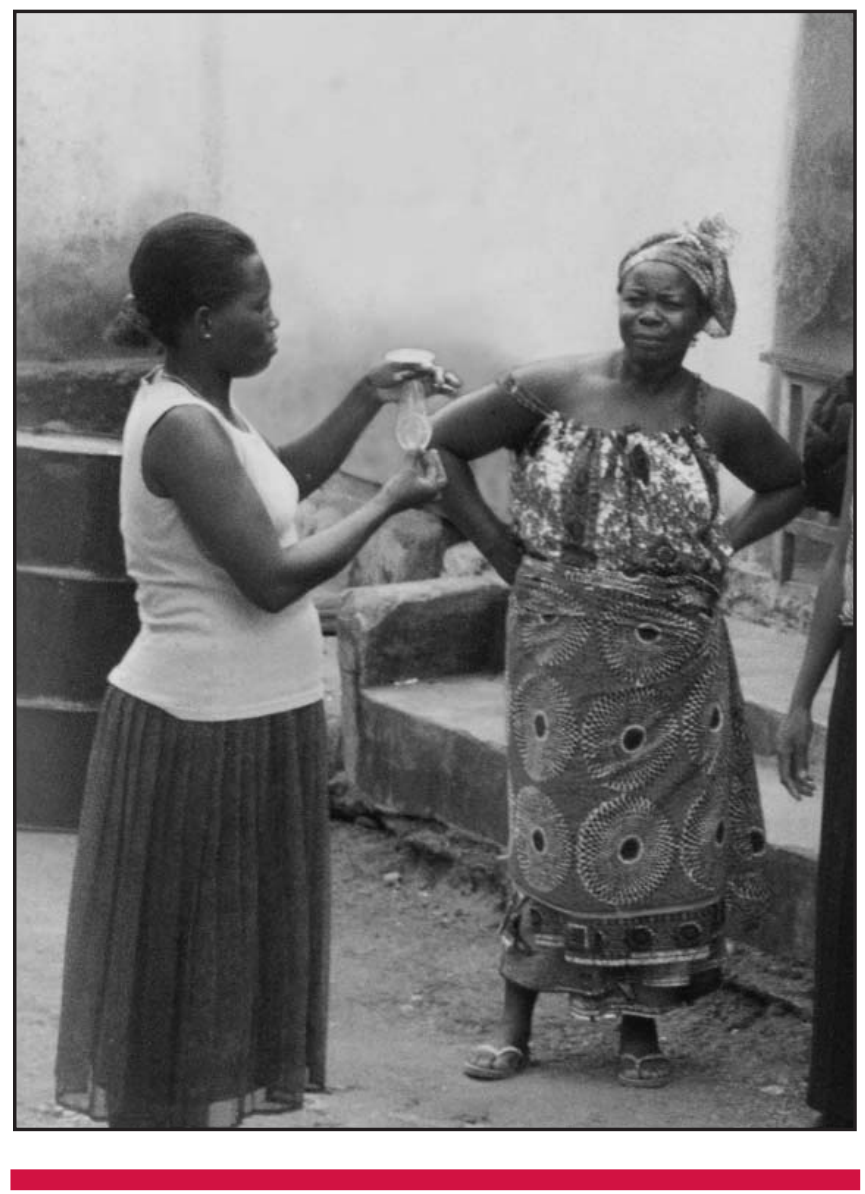

In Our Own Hands: SWAA-Ghana Champions the Female Condom 
Quality/Calidad/Qualité, a publication of the Population Council, presents case studies of high-quality, innovative programs in sexual and reproductive health. $Q / C / Q$ specifically documents educational and clinic-based programs that are making strides in one or more of the following ways: (1) addressing the central importance of gender dynamics in shaping sexual and reproductive health outcomes; (2) improving the quality of care of clinic-based services; and (3) reaching disadvantaged and underserved groups. With rare exceptions, featured programs are operating in developing countries.

Q/C/Q case studies_-selected by an expert advisory group-are offered not as models for replication, but as examples for learning. They demonstrate a responsiveness to broader social and economic transformations; they highlight inventive and affordable ways to respond to clients' needs; and they reflect the self-critical and flexible attitude required for learning from program experiences and research evidence. Although they are written as practical toolsin accessible style with carefully selected detail-they also serve to inspire program leaders and policymakers to enable clients to become more effective guardians of their sexual and reproductive health, and by doing so contribute fundamentally to the achievement of such broader aims as the Millennium Development Goals.

\section{Production Staff}

Editor: Debbie Rogow

Editorial and production coordinator: Michelle Skaer

Copyeditor: Karen Tweedy-Holmes

Designer: Mike Vosika

Translators: Charo Quesada (Spanish) and Genevieve Haines (French)

\section{Advisory Committee}

Delia Barcelona
Gary Barker
Carmen Barroso
Judith Bruce
Batya Elul
Susana Galdos
Françoise Girard
Nicole Haberland
Katherine Kurz

Laura Laski

Ann Leonard Ann McCauley Liz McGrory Manisha Mehta Suellen Miller Saumya Ramarao Ann Starrs Cynthia Steele

\section{(P) Population Council}

Publication of this edition of Quality/Calidad/Qualité is made possible by support provided by Family Health International; by the Robert H. Ebert Program on Critical Issues in Reproductive Health of the Population Council; by the Ford Foundation; and by the Gender, Family, and Development Program of the Population Council. Statements made and views expressed in this publication are solely the responsibility of the authors and not of any organization providing support for $Q / C / Q$.

The Population Council is an international, nonprofit, nongovernmental organization that seeks to improve the well-being and reproductive health of current and future generations around the world and to help achieve a humane, equitable, and sustainable balance between people and resources. The Council conducts biomedical, social science, and public health research and helps build research capacities in developing countries. Established in 1952, the Council is governed by an international board of trustees. Its New York headquarters supports a global network of regional and country offices.

Population Council, One Dag Hammarskjold Plaza, New York, NY 10017 USA

tel: (212) 339-0500 fax: (212) 755-6052 e-mail: qcq@popcouncil.org

Cover photograph by SWAA-Ghana.

Issue No. 17 ISSN: 1097-8194

Copyright (C) 2006 The Population Council, Inc.

Any part of this publication may be copied or adapted to meet local needs without permission from the Population Council, provided that the parts copied are distributed free or at cost (not for profit) and that the source is identified. The Population Council would appreciate receiving a copy of any materials in which the text is used. 


\section{Introduction}

\section{by Kathleen Cravero}

In 1992, a new product appeared on pharmacy shelves in developed countries-pink packets of female condoms. Doctors and journalists alike trumpeted the innovation. The method prevents both unwanted pregnancy and the transmission of sexually transmitted infections (including HIV), has a long shelf life, and allows for insertion for up to eight hours before intercourse. Even more important, its use is initiated by the woman.

Why a need for a method that places control in the hands of the woman? First, women and (especially) girls — of whom nearly 20 million are already living with HIV_account for an increasing proportion of new cases of HIV/AIDS around the world, with rates rising most rapidly in Asia, Eastern Europe, and Latin America. If current trends continue, women and girls infected with HIV could soon outnumber men and boys with the disease worldwide. In sub-Saharan Africa, women already account for almost 60 percent of those living with HIV, and three out of four HIV-infected young people are girls.

Moreover, the majority of women and girls who remain at greatest risk (as well as of those who are already infected) are vulnerable because of the behaviors of others, rather than as a result of their own choices. Although the traditional "ABC" prevention paradigm of Abstain, Be Faithful, and Use Condoms is a worthy goal, few women have the options they need to translate this strategy into reality. A number of social and economic factors combine to constrain women's ability to determine whether, when, and with whom they have sex. In some settings, girls are married off as children or are otherwise coerced into sexual relationships-usually with older men who are more sexually experienced. Because the double standard for sexual behavior prevails in many places, women commonly remain monogamous, knowing that their husbands have other sexual partners. Nevertheless, the decision regarding whether to use a male condom rests primarily with men, many of whom resist the idea.

No wonder the arrival of the pink packets raised hopes about reducing women's vulnerability to HIV globally. When used correctly and consistently, the female condom reduces risk of HIV transmission by 97 percent (Trussell et al. 1994). Studies conducted in more than 40 countries found acceptability rates ranging from 41 percent to 95 percent (FHI 2005). Twelve years after the female condoms first entered the market, the United Nations calculated that 64 million female condoms had been distributed in more than 100 countries.

The sad truth is, however, that this number is insignificant in light of the immense need for the method.

Why has the female condom so far failed to be adopted widely? Although limited acceptability is an issue (some women find that they or their partners simply do not like the method), a major central obstacle is set at the policy level -that is, the misguided tendency of many donors and program leaders to compare the method in narrow terms to the male condom. In such a comparison, the cost of the female condom (US\$0.58 to $\$ 0.72$ per unit, compared with $\$ 0.03$ for the male condom) seems prohibitive, especially for many users who live on less than a dollar a day. The contrast in price, however, is almost meaningless: As the following article shows, some men who refuse to use the male condom are

\footnotetext{
${ }^{1}$ Some women have found it difficult to insert without extensive practice; others dislike its visible outer ring.
} 
willing to have their partner use the female condom. To the degree that this pattern holds true, the lower cost of the male condom becomes moot. A more meaningful comparison is to the cost of projected cases of HIV.

Skepticism about the female condom is also based on the lack of continuing interest within some traditional service settings. Unlike the male condom, which has been distributed successfully through traditional provider systems, the female condom requires an education-based approach that seeks to raise women's awareness about their very right to protection. Schemes for female-condom distribution that do not enable women to assume and exercise this right are of negligible value.

As we accelerate work to make the female condom more available, affordable, and acceptable to both women and men, we must also extend efforts to alter prevailing gender norms. Throughout the world, a growing number of initiatives seeking to lower the barriers women face in accessing health and social services are confronting head-on such issues as violence, education, employment, and property and inheritance rights. For example, the UNAIDS-led Global Coalition on Women and AIDS is working with men and boys as well as with women and girls, advocating and supporting a range of strategies to change traditional beliefs and practices that reinforce pervasive gender inequality.

Normative change is slow. In the meantime, we must also provide women and girls with the information and-to the best of our ability-the means for preventing the spread of HIV. Today, the female condom remains the best tool for prevention available that provides women and girls with a measure of control over their own survival. Although promising progress is being made toward the development of a microbicide-a gel, cream, sponge, or suppository that women can use to protect themselves, if necessary without their partners' knowledge or consent-at least five to ten years will pass before an effec- tive microbicide reaches the market, even backed by sufficient political will and financial investment.

Happily, a growing body of evidence from various countries shows that in places where the female condom is being thoughtfully promoted and distributed, more and more women-and men-are saying that they want to use it. This news is encouraging and bodes well for ongoing efforts. Work is also underway to improve the female condom by making it not only less expensive and more accessible but also more comfortable and acceptable to male partners. A new model, which has been well received in Mexico, South Africa, and Thailand, is currently undergoing clinical trials in the United States and could reach the global market within the next two years.

Hence, a renewed programmatic effort is afoot to promote the female condom. The following article describes an innovative initiative in Ghana and includes shorter descriptions of efforts in Brazil, South Africa, and Zimbabwe. The Ghanaian project brought together a diverse range of partners-including the government, UN agencies, NGOs, and the Female Health Company-to enable large numbers of women to obtain female condoms at an affordable price. The program's success is a tribute to the value of an effective multisectoral partnership, to the female-empowerment strategy launched by the Ghanaian branch of the Society of Women and AIDS in Africa, and to the thousands of women who recognized that their lives were at stake and seized the opportunity to act on their own behalf.

\section{References}

Family Health International. 2005. "Female Condom Acceptability and Sustained Use." FHI Research Briefs on the Female Condom No. 4. $<$ http://www.fhi.org/en/RH/Pubs/Briefs/fcbriefs/ acceptability.htm>. Accessed 15 December 2005.

Trussell, James, Kim Sturgen, Jennifer Strickler, and Rosalie Dominik. 1994. "Comparative contraceptive efficacy of the female condom and other barrier methods." Family Planning Perspectives 26(2): 66-72. 


\section{In Our Own Hands: \\ SWAA-Ghana Champions \\ the Female Condom}

by Michelle Skaer and Victoria Ebin

A group of women hotel workers watches intently as Rebecca Attipoe, a member of the Society for Women and AIDS in Africa (SWAA), holds a small, clear, plastic item, which she calls a female condom. Using the device does not look easy to these women. Talking to their sexual partners about it seems even more difficult. Worrying every night about AIDS and unwanted pregnancy, however, seems harder still. After Rebecca answers their questions, several women step forward. With their health and lives at stake, they decide to try it.

These women, like 75 percent of all women in Ghana, enjoy a measure of economic autonomy. Working primarily in farming and informal employment, one out of three are the heads of their households (GSS et al. 2004). Despite their economic role, however, most Ghanaian women have little power over sexual decisions affecting their health and lives. Typically, they cannot insist upon fidelity from their husbands, much less from extramarital sexual partners. Nor can most require their partners to use protection against infection or unwanted pregnancy; use of contraceptives, and of male condoms in particu- lar, remains low. ${ }^{1}$ Commonly, moreover, women are coerced to have sex. As one Ghanaian reproductive health professional has commented, "Most women own houses but still need educating in how to negotiate [sex]" (Akai-Nettey 2003).

Around the world, gender inequality in sexual decisionmaking puts women at particular risk of health consequences. Of particular concern, of course, is HIV/AIDS. Compared with other African countries, the HIV prevalence rate in Ghana is relatively low: 3.6 percent of the adult population, with a rate of 5.3 percent in some regions (NACP 2001). The virus, however, disproportionately affects women and girls. Among 15-24year-olds, the HIV rate is more than four times higher for females than for males (NACP 2001:17).

Until the late 1990s, the Ghanaian government's HIV/AIDS programming was limited. ${ }^{2}$ Ghana's well-established family planning program continued to emphasize long-acting methods, such as Norplant $^{\circledR}$, rather than barrier methods that offer protection against HIV/AIDS and many sexually transmitted infections (STIs). Public awareness about HIV/AIDS

\footnotetext{
${ }^{1}$ The DHS found overall contraceptive use among currently married women to be 25.2 percent, with the pill accounting for 5.5 percent, injectables for 5.4 percent, periodic abstinence for 5.1 percent, and male condoms for 3.1 percent (GSS and MI 2004).

${ }^{2}$ The first education campaign began in 1986; the National AIDS Policy was drafted in 1996; and in 2001 the National AIDS Commission was established.
} 
and condoms was close to universal; however, local studies found that only 42 percent of men perceived themselves to be at risk of infection. In one survey, only 16 percent of adult men and 6 percent of women reported using a condom during their most recent sexual encounter (GSS and MI 2000).

In recent years, several factors have heightened the sense of urgency about the epidemic. First, the HIV rates in neighboring countries - which are two to three times higher than those in Ghanaunderscore the risk of rapid spread of the virus. (The discrepancy between the rate in Ghana and the rates across its borders also raises concerns about whether Ghana's reported rates of infection may be underestimated.) Approximately 200 people in Ghana become infected with HIV each day. Moreover, at least threefourths of female sex workers in Accra and Kumasi, the two major Ghanaian cities, are HIV-positive.

\section{Society for Women and AIDS in Africa (SWAA)}

Across the region, an early driving force for attention to HIV/AIDS, and in particular, to women's needs with regard to the epidemic, has been the Society for Women and AIDS in Africa (see box below: SWAA International). In the late 1990s, however, the Ghana branch of SWAA was small and relatively inactive. The organization, with no funding or paid staff, had not undertaken any large projects. Two of its leaders, Alice Lamptey and Bernice Heloo, had been involved in their professional lives in small acceptability trials of the female condom, but SWAA-Ghana had not begun to advocate for the method.

Two incidents changed the organization's path.

First, Alice Lamptey and Bernice Heloo were invited to represent SWAA in a working group established specifically to

\section{SWAA International}

Around the world, women have responded collectively to the AIDS epidemic. One of the earliest and bestestablished of the women's organizations-with affiliated branches in eight countries, including Ghana-is the Society for Women and AIDS in Africa (SWAA). Initially, SWAA focused on care (including improving access to antiretroviral drugs) for people living with HIV as well as support for them, for their children, and for AIDS orphans. By the late 1990s, the organization also began to focus on methods of preventing transmission of the virus, advocating for access to the female condom and for research toward the development of an effective microbicide (SWAA 2004). The eight SWAA branches range in size from a single woman to large groups (composed primarily of volunteers with some paid staff). Some operate without any funding, whereas others have strong donor support. Some branches focus on providing direct services and community care, and others lead advocacy and educational campaigns. SWAA International, based in Senegal, provides assistance to the all of the loosely affiliated branch offices through capacity-building and communications support.

For more information, visit <www. swaainternational.org $>$. 
introduce the female condom into Ghana. This working group arose out of the government's AIDS task force, in which members learned from the UNAIDS (the Joint United Nations Programme on HIV/AIDS) and UNFPA (United Nations Population Fund) representatives (Cynthia Eledu and Moses Mukasa, respectively) about the successful experience with the method in South Africa. The AIDS task-force members decided to establish a working group that included the government, international organizations (UNAIDS and UNFPA), and selected nongovernmental organizations (NGOs), including SWAA.

At about the same time, Alice Lamptey attended an international SWAA meeting in Dakar, where members were enthusiastically promoting an organization-wide campaign for the female condom. Lamptey knew that SWAA-Ghana had gained, through the new working group, an important avenue for making the female condom a viable option for women in her country. She also knew that in order to take advantage of that opportunity, the Ghana branch would have to be revitalized.

On her return to Accra, Lamptey set to work. SWAA-Ghana reorganized its structure, holding its first general election; Charity Binka, a well-known journalist and women's activist, became its first president. An executive committee appointed four members to manage a female condom promotion project. Beyond collaborating with the government's working group to introduce the method, SWAA's project plan called for the organization to operate its own network for distributing it directly to users. Funds were secured from the Danish International Development Agency (DANIDA) and from UNAIDS. The organization established an office and hired Rebecca Attipoe as the project coordinator.

Nothing inspires like having a mission, and now SWAA-Ghana had found one.

\section{SWAA's Role in the Female Condom Working Group}

SWAA-Ghana joined the female condom working group along with three other NGOs: the Ghana Social Marketing Foundation (GSMF), Planned Parenthood Association of Ghana (PPAG), and the Ghana Registered Midwives Association. For the most part, the group members were already well acquainted with one another. For example, Lamptey wore "two hats" on the working group; she also worked at the Ghana Social Marketing Foundation. Indeed, the involvement of the NGO representatives enlivened the working group and created a strong sense of partnership.

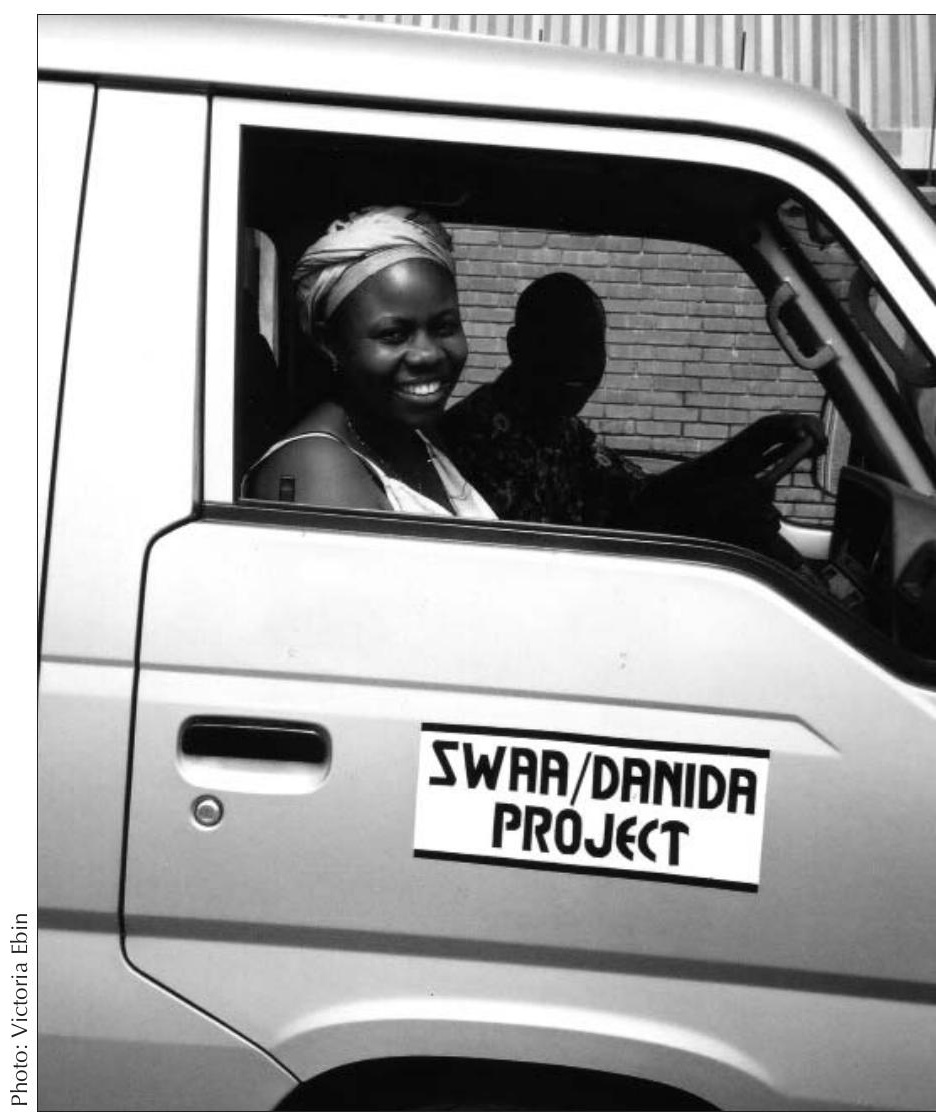

SWAA mobilized to promote the female condom; with funds secured from DANIDA, the organization established an office, hired Rebecca Attipoe as project coordinator, and purchased a truck. 
SWAA played an integral role from the outset; Alice Lamptey, together with her colleague Kojo Lokko of GSMF, drafted a strategy proposal for the group.

This document outlined the female condom introduction process and identified a number of issues on which the group developed an easy consensus. For example, drawing on acceptability data from more than 40 countries, the group decided against investing time and resources on another comprehensive acceptability study. Another key decision concerned defining the target user population. The group wanted to avoid the negative association with sex workers that had hindered the female condom campaigns in other countries. Accordingly, they decided to position the method as a "mainstream" contraceptive barrier that protects against unwanted pregnancy and HIV infection and to market it widely. The target user population included all sexually active men

\section{The Ghana Social Marketing}

Foundation tested the product at

this price by placing 8,000 female

condoms in 160 pharmacies. The

entire inventory was sold within

a week. through various channels. The government and Planned Parenthood agreed to offer the method in their clinics; the Ghana Social Marketing Foundation assumed responsibility for arranging pharmacy sales of a more expensive "brand-name" female condom; the Ghana Registered Midwives Association agreed to promote the method among its clients; and the West Africa Project To Combat AIDS enlisted to reach out to sex workers and to other women through midwives. SWAA's role was to distribute the female condom through its local networks, focusing on the regions with the highest HIV-infection rates and the communities not reached by other programs. Although SWAA had never been involved with large-scale commodity supply, the organization was prepared to invest in developing the institutional infrastructure and skills to carry out its role in the cooperative plan.

\section{The Fight Over Pricing}

The most difficult issue facing the working group was establishing a unit price for the female condom, and on this matter, SWAA fought an uphill battle. To enable programs to provide the method with limited outside support over the long term, some working group members suggested a unit price of 6,0008,000 cedis (at the time approximately US\$1). SWAA balked and a conflict ensued. Alice Lamptey recalls that she protested, "Men's condoms cost 100 cedis, and women should pay 8,000? How can we ask women to pay that? You're telling them to go to hell and get infected. If we fix the price above what women can afford, we will be condemning them to HIV infection."

To ascertain how much women would actually pay, the working group asked

\footnotetext{
${ }^{3}$ The global public-sector price was set in 1996 by UNAIDS and the manufacturer, the Female Health Company.
} 


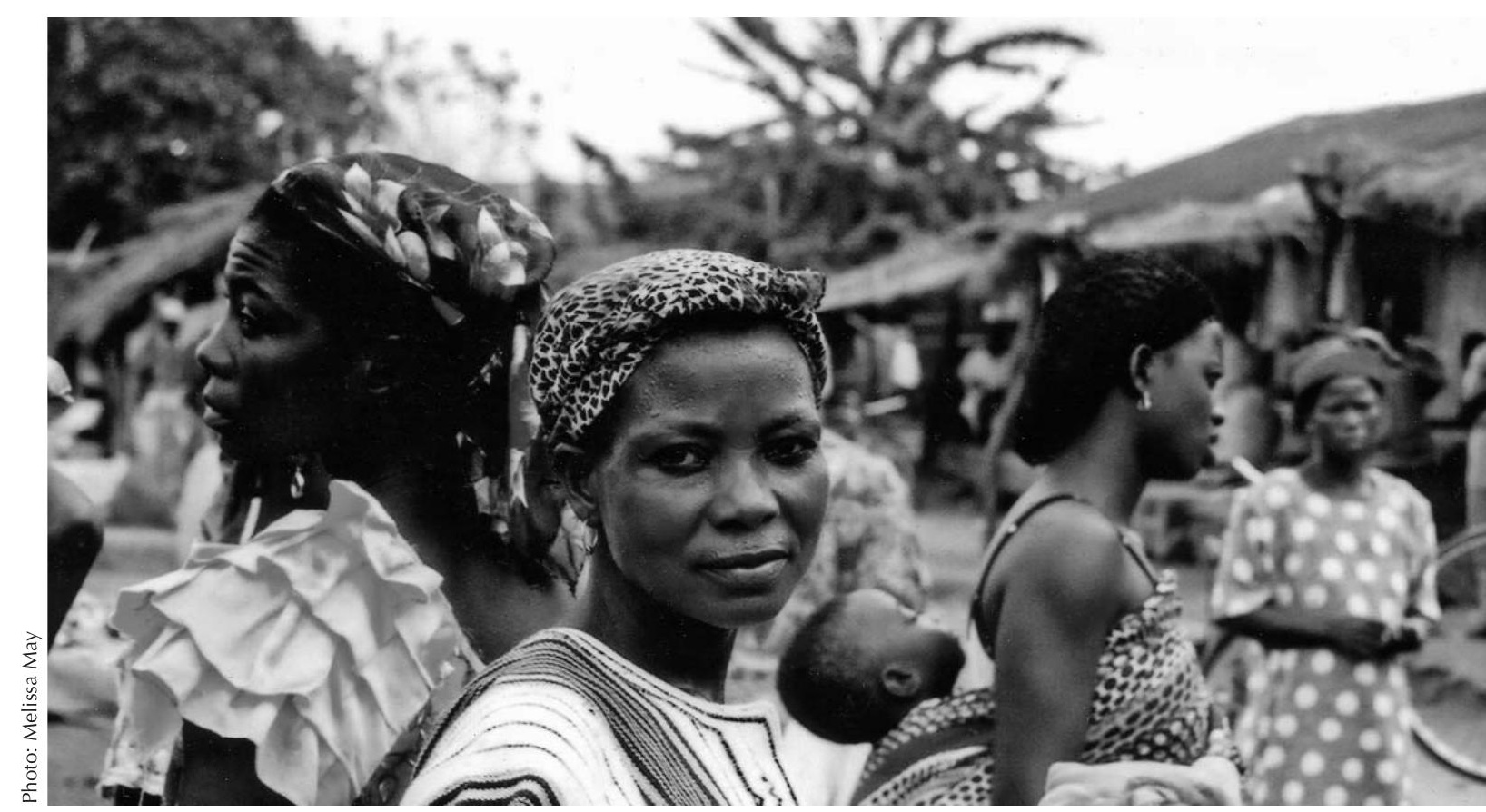

The Ghana Social Marketing Foundation undertook market research to determine a price that women could afford. Alice Lamptey argued that a reasonable price "was a matter of equity. . . . We cannot discriminate against women."

the Ghana Social Marketing Foundation to undertake further in-depth market research. Almost all respondents said they would buy the female condom if it cost the same as a male condom (100 cedis, or less than \$0.02). The average acceptable price named by respondents was 450 cedis (GSMF 1999). ${ }^{4}$

At the next meeting, the working group slashed the proposed price from 8,000 to 500 cedis (\$1.12 to $\$ 0.07$ ), but Lamptey argued that the lowered price still placed too great a burden on poor women at risk of HIV infection and predicted that, at 500 cedis, the method would stay on the shelves. SWAA understood that the relatively high unit price of the female condom strained donor budgets, but argued that it was a good investment from both a public health perspective and as a women's rights issue. Lamptey recalled that "It was a matter of equity. . . . We cannot discriminate against women."

SWAA's efforts to restructure donor priorities prevailed. At the final meeting before the introduction, Moses Mukasa of UNFPA agreed that the agency would subsidize the extra cost. The female condom would be sold for 300 cedis (\$0.04). The Ghana Social Marketing Foundation tested the product at this price by placing 8,000 female condoms in 160 pharmacies.

The entire inventory was sold within a week.

\footnotetext{
${ }^{4}$ The study also attempted to gauge the strength of market demand. Two-thirds of respondents stated that they did not consider themselves at risk of acquiring HIV infection. Forty-four percent reported that they had taken action within the last three months to avoid becoming pregnant; the greatest proportion (19 percent) were relying on the male condom. About 40 percent of respondents had heard of the female condom, but only two of 468 respondents had ever used it.
} 


\section{SWAA Helps Lead the National Training}

SWAA played an important role in designing and implementing the female condom working group's two-day training of trainers (TOT) workshops. Representatives from the Ministry of Health $(\mathrm{MOH})$ and all participating NGOs (including ten SWAA members) attended the first round of TOT workshops, which drew on materials produced by the manufacturer (the Female Health Company) $)^{5}$ and included the following topics:

- Clinical aspects and prevalence of HIV/AIDS

- How gender inequality increases women's vulnerability to HIV

- Overview of the female condom (with emphasis on dual protection against infection and pregnancy)

- Education and counseling issues (including negotiating skills)

- Logistics (supply, distribution channels, storage, reporting)

- How to plan a training for direct distributors

The trainers demonstrated proper use of the method using a plastic model. They also encouraged female participants to try inserting the method during the night between days one and two of the workshop, and later to insert it eight hours in advance of a time they anticipated having sex. Trainees' likelihood of trying the method varied, depending, in part, on the effectiveness of the trainer.

\section{The Public Launch of the Method}

The TOT participants went on to train 4,400 direct distributors, from clinic staff and pharmacists to hairdressers and tailors (Glasgow 2001). UNAIDS distributed a total of 15,000 female condoms for the trainers and direct providers to use during educational demonstrations.

SWAA cooperated with the working group in planning a public education campaign to introduce the female condom formally in Ghana. The official launch of the introduction process took place on 25 May 2000 at the National Theatre in Accra. More than 1,500 people attended the high-profile event. A representative of the First Lady of Ghana delivered the keynote speech. Political leaders, representatives from international organizations, traditional chiefs, and "queen mothers" were all in attendance. The NGOs participated, as did women's associations, market sellers, and hairdressers. The event even included a "mascot" in a female condom costume (UNAIDS and WHO 2000).

Alice Lamptey and Bernice Heloo shared with their fellow working group members a sense of excitement and momentum about ushering in a new stage in HIV prevention. SWAAGhana, however, was about to take a different approach in carrying out its promise to help distribute the female condom.

\footnotetext{
${ }^{5}$ The Female Health Company (FHC) was founded on the belief that women have the right to protect themselves against HIV and other infections and have need for a technology to enable them to exercise that right. FHC manufactures the female condom, holds exclusive worldwide rights to its design, and currently distributes the method to 80 countries through public-sector procurement and commercially in 17 countries. In 1996, FHC formed a foundation to carry out advocacy and education activities promoting women's health and reproductive rights around the world (see www.femalehealth.org).
} 


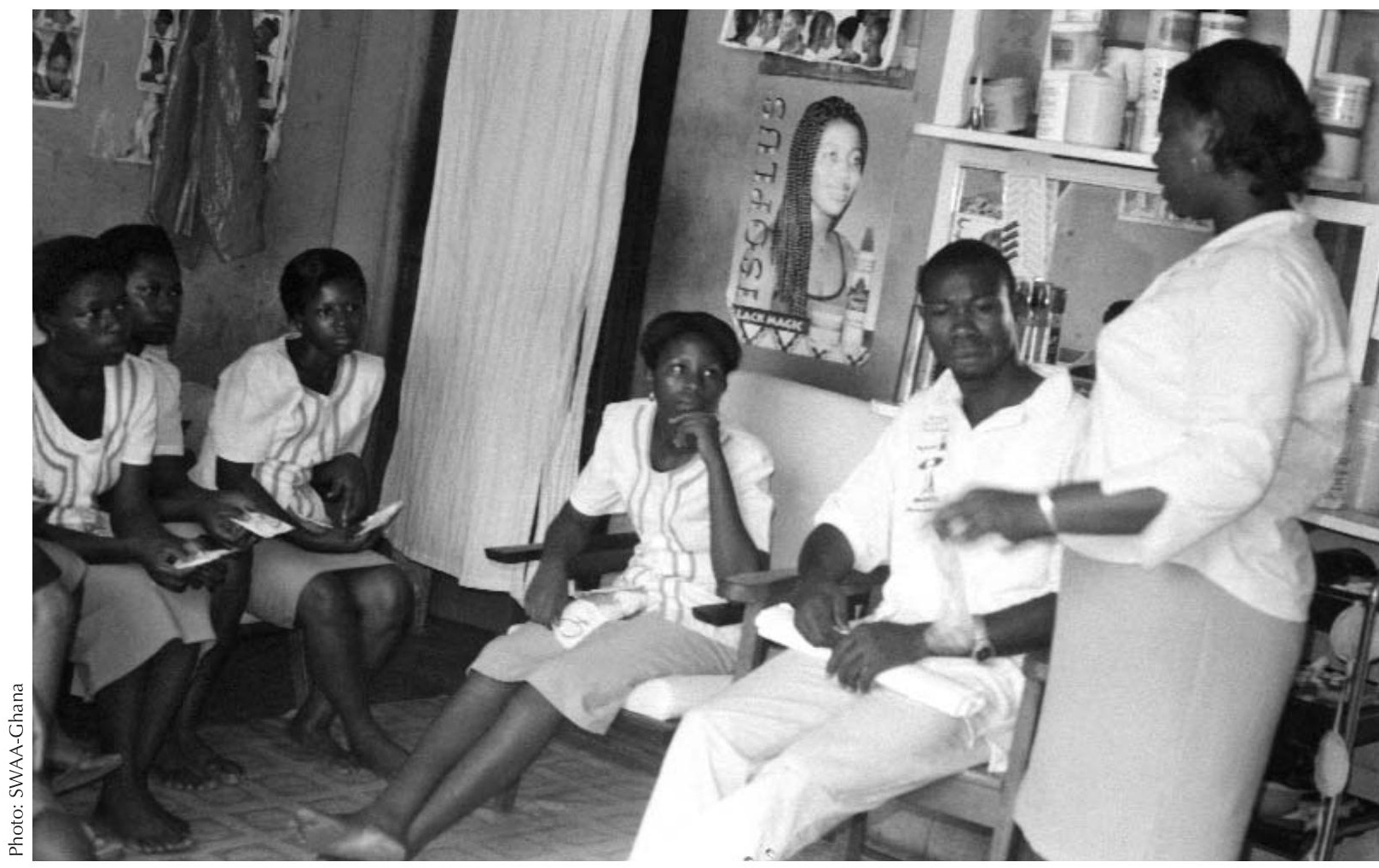

Hairdressers, who interact on a daily basis with members of their community, make ideal female condom promoter-distributors. SWAA prepared them to offer women information, supplies, and the communication skills needed to start a dialogue with their partners on sensitive topics.

\section{Recasting Commodity Distribution as an Education Package}

Taking on direct distribution of a technology was a new challenge for SWAA, and the organization charted its own course. In terms of institutional capacity, the organization was not fully prepared for the task. In terms of its creative vision, however, SWAA was perhaps the ideal organization to introduce the female condom across Ghana. Indeed, the organization's approach turned traditional commodity distribution on its head: Instead of focusing first on the details of a particular method or on racking up a number of "acceptors" (with counseling as an add on), SWAA felt that its main job was to convince women that they had a right to protect their own lives and to provide them with some basic skills in negotiationand a technology in their hands-to exercise that right. In this case, the technology happens to be the female condom; substitute another technology (for example, a microbicide), and the basic strategy would remain the same. As Rebecca Attipoe, the project coordinator, described this moment, "SWAA became involved with the female condom because it is woman-controlled. Now that the government and partners had put a structure in place for the female condom, SWAA could reach women with an empowering message about the method."

SWAA leaders understood that women need to learn about a method 
like the female condom in the context of a frank discussion-about their sexual relationships, about the sexual practices of the men in their lives, and about what is involved in inserting the method into the vagina. As one SWAA representative commented, "It's crossing a big social barrier for women to talk about sex." SWAA believed that a grassroots effort was the most effective way to foster such conversations. Discussions about the female condom were embedded in, and opened, larger conversations about sexuality, reproduction, and power within male-female relationships.

The distribution project was, at its heart, an empowerment campaign, and SWAA threw itself into the task. The organization developed a system for procuring commodities from the government and purchased a truck. Staff also adapted the existing training and materials. For example, they changed the message on the national promotional poster from "Safe, Simple and Reliable" to "Safe and Reliable." As Rebecca Attipoe says, "It's not all that simple, and we don't want women to lose their confidence if they don't get it right at first." On the national brochure, they replaced the image of a middle-class woman in a suit with a woman in traditional dress. "She could be a farmer or market woman," remarks Rebecca. "This is who we need to reach."

It is unusual for an advocacy NGO to field an army of commodity suppliers, but the female condom is not a typical technology. SWAA kept its eye not on women's compliance with a set of instructions but on their increased sense of agency. Ultimately, within the Ghanaian context, SWAA has proved most capable of promoting the female condom.

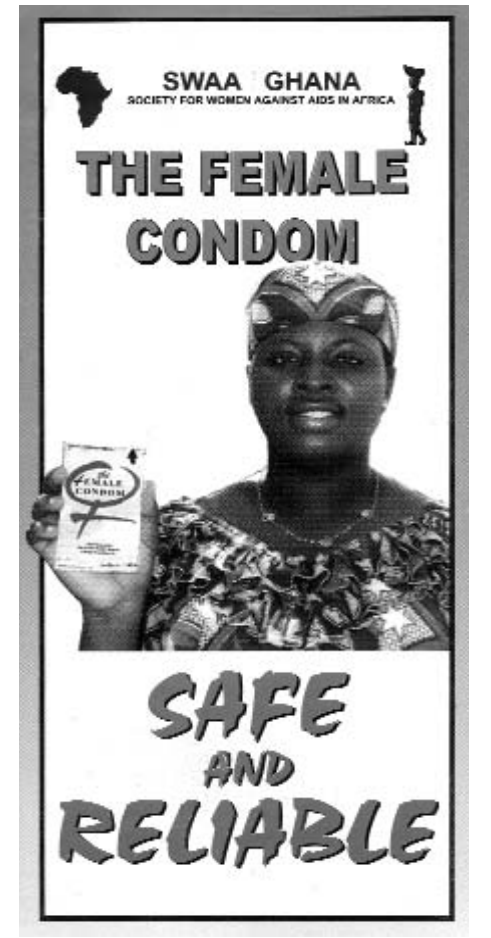

By the end of 2000, the 1,000 SWAA distributor-promoters had sold (or had given away) about 170,000 female condoms.

\section{Recruiting and Training SWAA Distributors}

By the end of 2000, the number of SWAA trainers had grown from ten to 80. Through local associations in urban and rural areas, these trainers began offering one-day workshops to individuals who wanted to become direct distributor-promoters. The priority was on reaching individuals-for example, hairdressers, market women, and seamstresses - who interact on a daily basis with members of their community. ${ }^{6}$ In hopes of promoting support among

\footnotetext{
${ }^{6}$ Rebecca Attipoe explained that female apprentices (such as those learning to be seamstresses) are among those in greatest need of a method to protect themselves, because they are on their own for the first time, and they often have to depend on men to survive.
} 


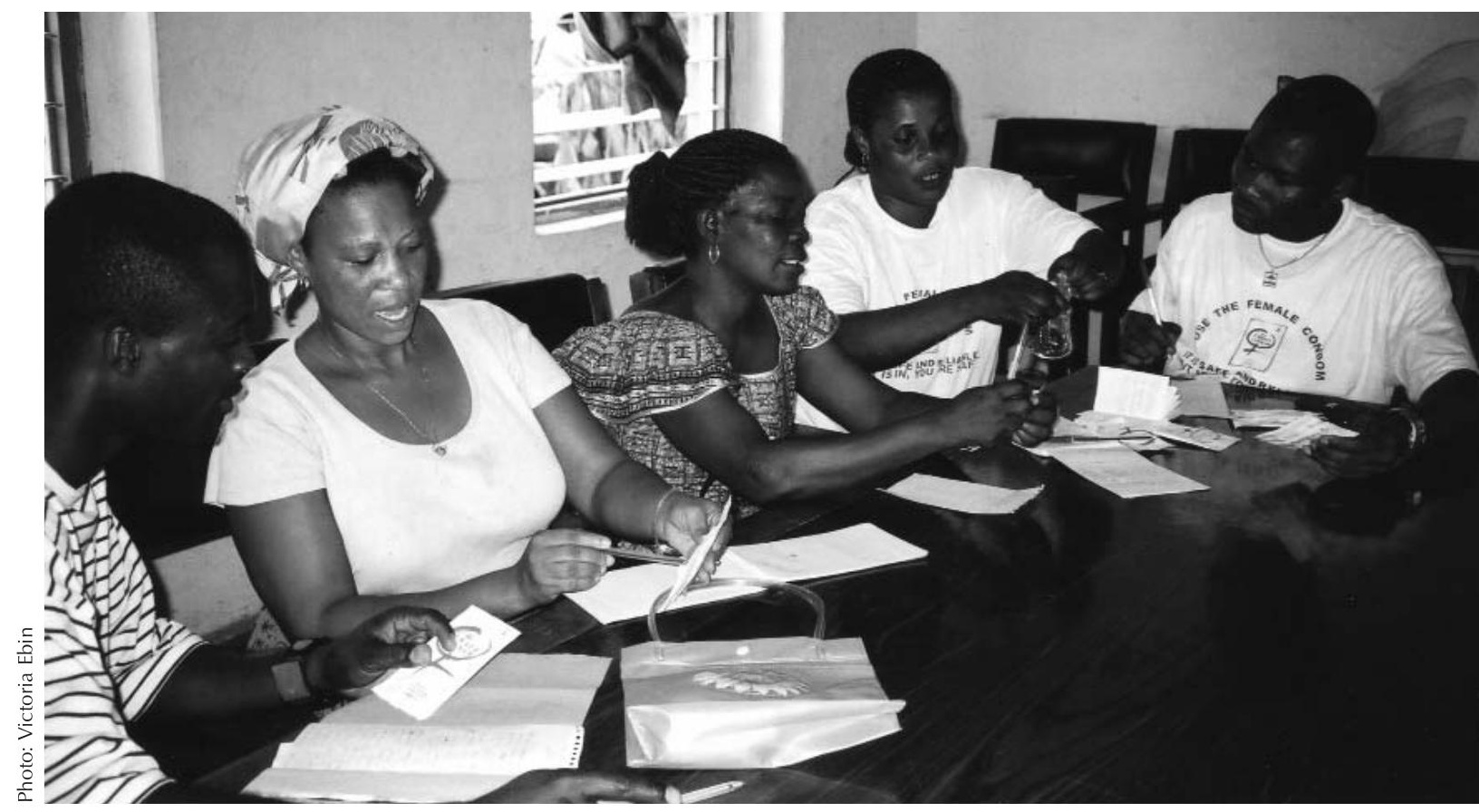

SWAA trainers recruited distributor-promoters over several months until they had trained about 1,000 people. In a follow-up meeting, distributor-promoters offered feedback on the training, reporting that the session vastly increased their knowledge of HIV and STIs. One woman admitted that before the training, she thought AIDS did not really exist.

men, SWAA also recruited local male leaders to help distribute the female condom.

In Ghana's Western Region, SWAA members Elizabeth Ennuson, Margaret Asantinwa Sackey, and Agatha Aggrey set out to recruit 100 distributorpromoters at a workshop. They contacted dozens of associations-youth and women's organizations, Christian ministers and congregations, social clubs, fishmongers, students, market women, Muslim women's groups, hairdressers, and associations of the wives of police and of prison officers. They also informed potential participants that transportation costs and lunch would be paid by SWAA. To their amazement, three hundred people attended, including students, housewives, and religious leaders.

SWAA trainers continued to recruit over a period of several months, until they had trained about 1,000 people to promote and distribute the female condom; ${ }^{7}$ at least one-third of the trainees were men.

The training for potential distributorpromoters was a combination of social analysis, technical information, and skill-building for talking about sexuality. The SWAA trainers taught participants about HIV and about how women become particularly vulnerable to the disease. They also explained what the female condom is and how to

\footnotetext{
${ }^{7}$ This number compares with 300 distributor-promoters trained by the Ghana Midwives Association and 55 trained by Planned Parenthood Association of Ghana. The $\mathrm{MOH}$ and the Ghana Social Marketing Foundation trained nearly 3,000 individuals each, but the distributors reached by these groups were not expected to organize group meetings, discuss sensitive sexual issues, or teach women sexual negotiation skills. Hence, SWAA positioned itself to reach directly the greatest number of possible users.
} 
demonstrate its use. Finally, they prepared the participants to help women negotiate use of the method with their husbands.

Elizabeth, Margaret, and Agatha were hoping for an audience of 100 potential distributor-promoters. Three hundred attended, among them students, housewives, and religious leaders.

In a voluntary follow-up meeting several weeks later, 30 participants offered feedback on the one-day promoters' training and on their initial experiences. These individuals reported that the session had vastly increased their knowledge of HIV and STIs. A number of the trainees agreed with a woman named Alima, who admitted that before the training, she thought AIDS did not really exist. All of the participants reported being deeply affected by seeing the film about STIs, "The Silent Epidemic." Most were enthusiastic about promoting the female condom. One man said he was planning to attend a football match, where he could speak with men about the female condom after the game; others commented that many men are more comfortable with learning about the female condom in a private setting. A trader boasted that she could reach the greatest number of individuals, because she interacts with people all day long. An adolescent boy stated, "We young boys need to see things with our own eyes. If I have the female condom with me, I can show it to others."

\section{In the Field with}

SWAA

To promote its activities, SWAA's central project staff produced t-shirts and radio shows, and conducted a four-day drama and puppetry workshop for 30 distributors. They also kicked off a broad outreach campaign to selected audiences. For example, they cultivated affiliations with local women's associations, sponsored a workshop on the female condom for 75 media representatives, cooperated with a network of ten hotels to place female condoms in guest rooms, and trained health personnel who work with AIDS patients. As part of their effort to reach men, SWAA representatives began offering talks to groups of soldiers. To link the female condom project to other human rights work, the organization also established a cooperative relationship with an international NGO that buys freedom for women who are essentially held as slaves at religious shrines (and forced to have sex with shrine workers who typically have multiple partners, putting these women at risk of HIV infection). SWAA provided 2,000 female condoms to the newly freed women.

A particular challenge was reaching out to the religious community. SWAA knew that churches could provide another important avenue for reaching people, but historically they did not have a strong foothold in churches, and they knew that speaking openly about sex might shock church members. The organization secured funding to provide outreach to the religious community. One religious leader became an active distributor-promoter of the female condom (see box on page 14: Preaching Protection). 


\section{How Ghanaians Responded}

SWAA found that women were intensely interested in the idea of saving their own lives and in the funny little device that was introduced as making that notion feasible. Alice Lamptey reported, "Everywhere our network members go in the country, they are bombarded with requests for the female condom. To our surprise, men are also requesting the condom." By the end of 2000, the 1,000 SWAA distributorpromoters had sold (or had given away) about 170,000 female condoms.

The effort to reach out to the religious community paid off well. SWAA trainers were able to speak to congregants in many churches. Lamptey says that some of the more conservative church leaders warned her to "just do the talk and not the demonstration." In these cases, however, she would tell women that anyone who wanted to learn more should come to see her after the talk. After these talks, she invariably found her car mobbed by women wanting information and sam-

\section{When Lamptey was demonstrating}

the female condom in a church in

the Medina, the congregants

apparently expected the pastor to

stop her. Instead, he stepped up

to the platform and demonstrated

how to insert it.

ples of the female condom. "The young people always came first and the adults would be on the fringes, trying to hear," she explained. Lamptey also reports that no congregation ever has chased her out. Indeed, on one occasion, when she was demonstrating the female condom in a church in the Medina, the congregants apparently expected the pastor to stop her. Instead, he stepped up to the platform and demonstrated how to insert it.

In 2003, SWAA conducted an evaluation of its efforts. Project staff surveyed 25 distributor-promoters and 227 beneficiaries (defined as individuals who had taken

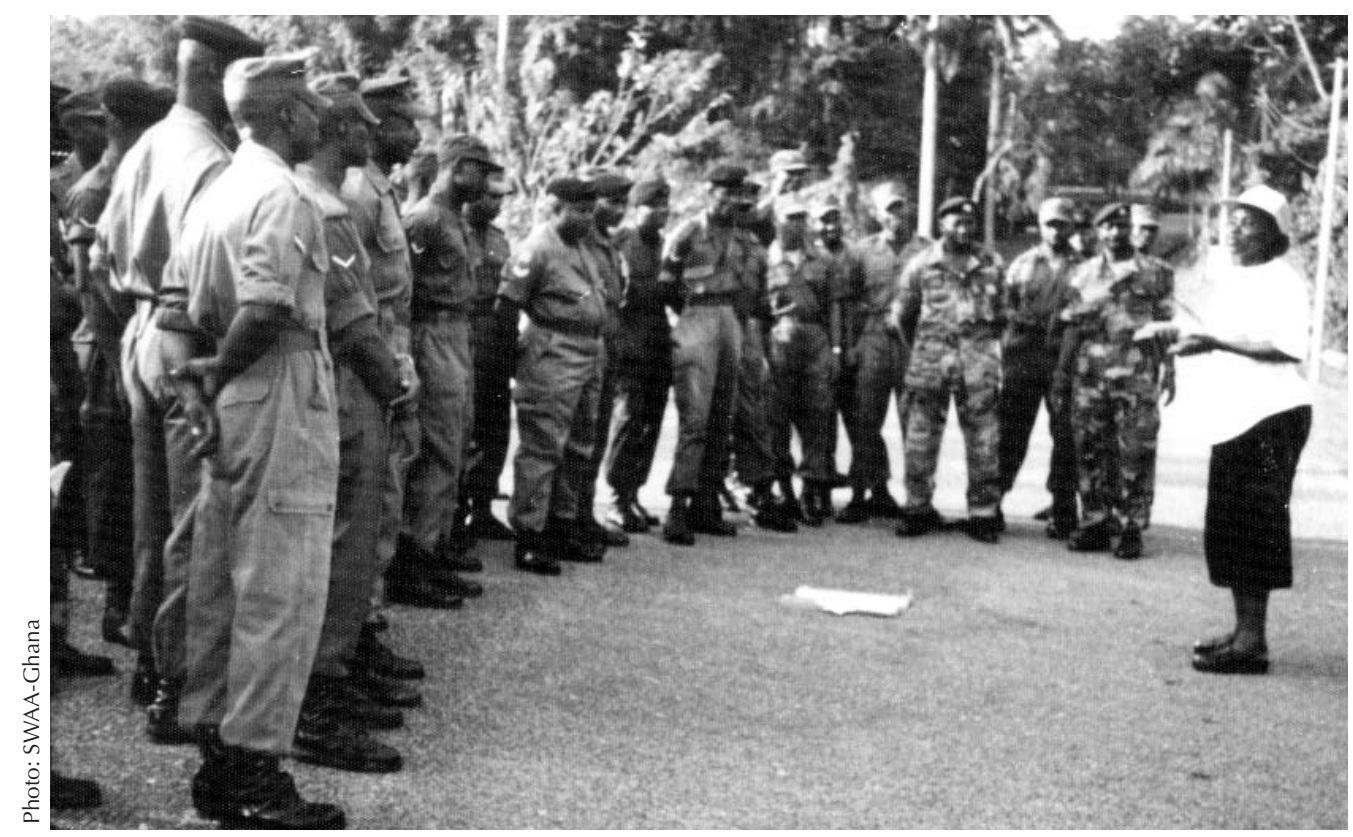

As part of their effort to reach men, SWAA representatives began offering talks to groups of soldiers. 


\section{Preaching Protection}

For John Edem Hini, deacon of an evangelical church, the female condom became a new mission. Since attending a SWAA training, Hini has been speaking at schools and churches, presenting the female condom as a tool for birth spacing. He buys ten female condoms at a time and, using a foam model, shows people how to open, insert, and dispose of the method. At one church retreat, Hini spoke to 3,000 people. He has also trained a handful of church members to teach others. In addition to church activ- ities, he owns the "Heavy-Do Electronic Shop," which is decorated with signs and posters about AIDS.

According to Hini, none of his congregants has objected to his activities; for the most part, people are curious about the method. He speaks critically of programs that distribute only male condoms: "We must encourage the promotion and distribution of the female condom equal [to] that of the male condom-to empower women . . . irrespective of their religion, tribe, or status in society."

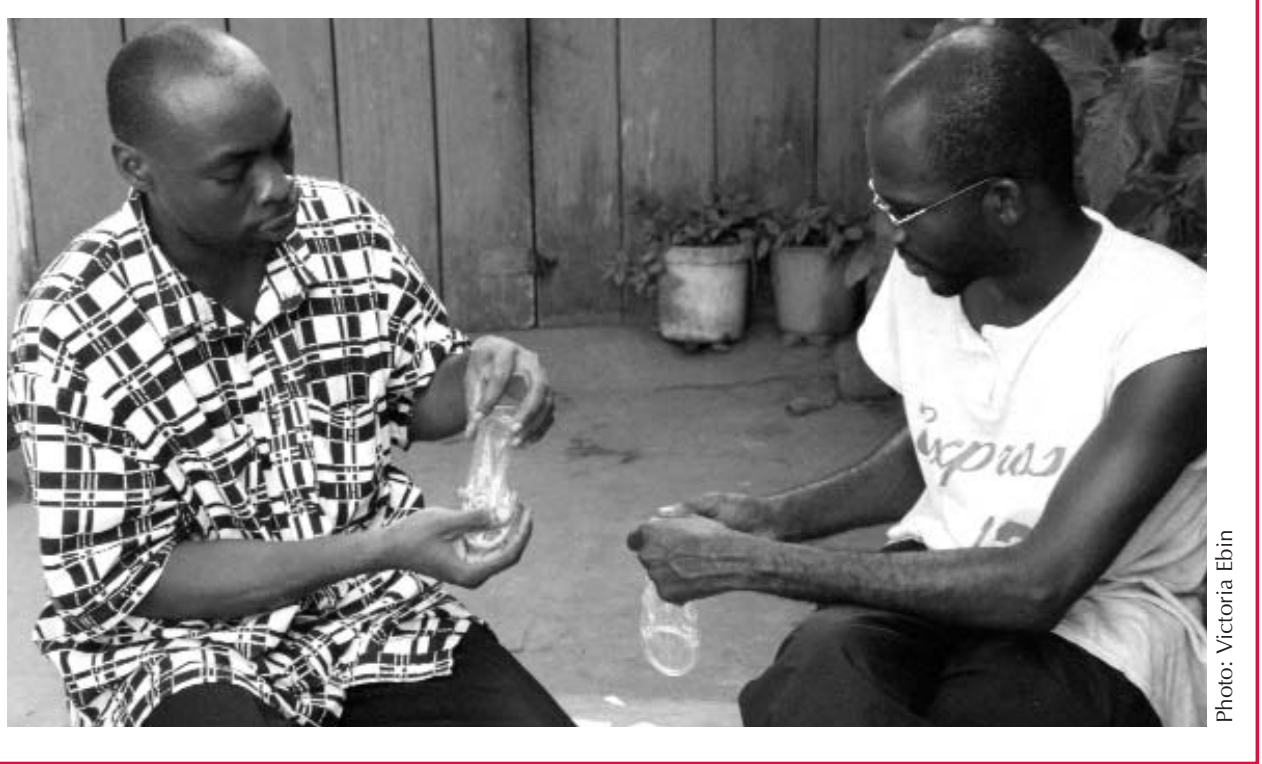

the female condom home). The results indicated that 90 percent of distributors and users had shared information about the female condom with friends or family members. Seventy-nine percent had discussed method use with her or his partner; among these couples, 87 percent of partners agreed, immediately or eventually, to try the method. Men as well as women were purchasing the condoms.

At the time of the survey, not all of these couples had tried the method, however: Among the promoters, 87 percent had ever used the female condom; among the general beneficiaries, 60 per- cent had tried it. Of the group of everusers, two-thirds were continuing to use the female condom. Among this group, 47 percent reported using the method always or most of the time. (These data were corroborated by responses to questions about how many times the method was used in the previous five sexual encounters: 34 percent reported using it all five times, and another 21 percent stated that they had used it three or four times.)

The evaluation also documented problems with management information systems, counseling, and outreach in areas that lack radio. 


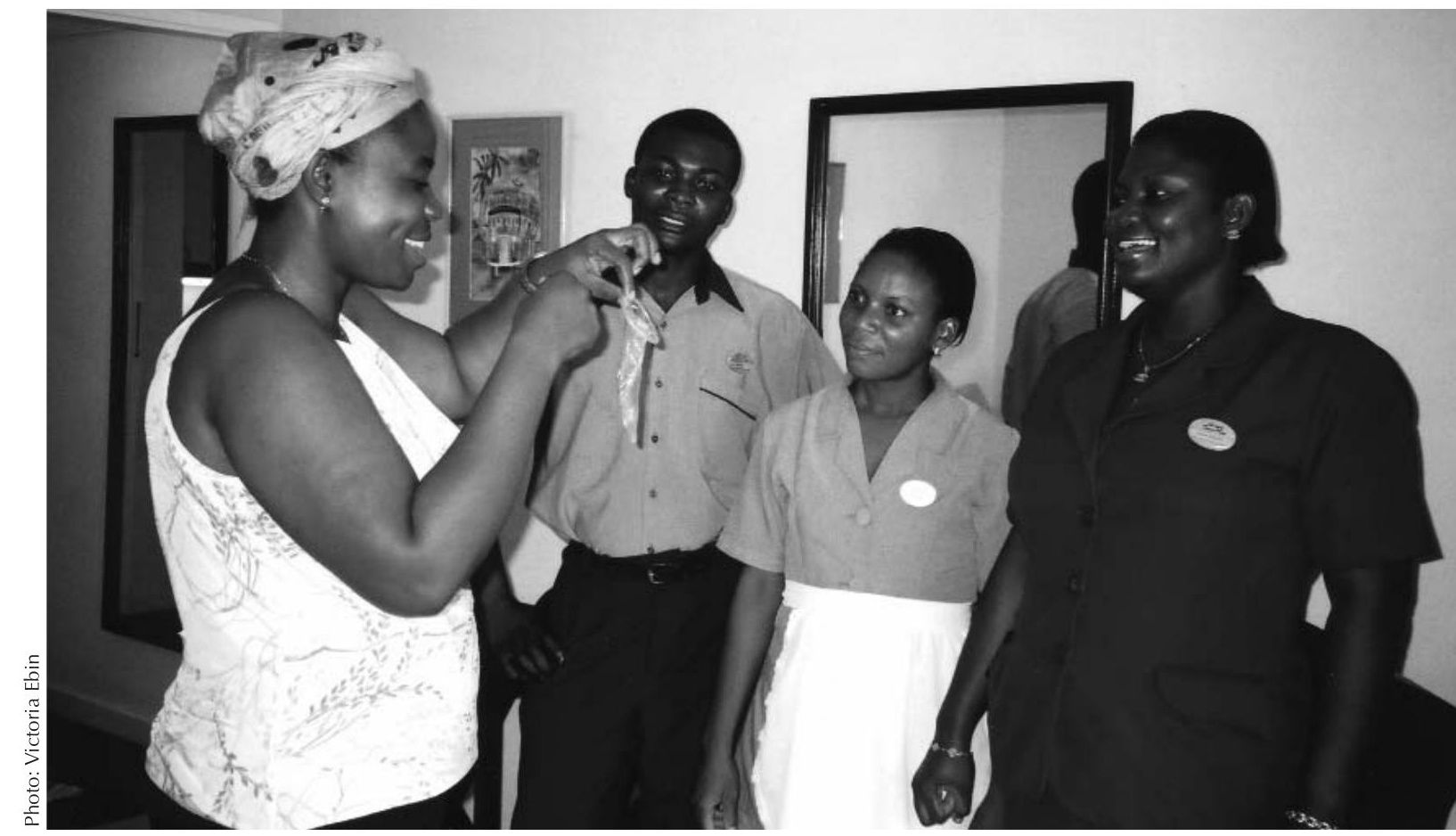

Rebecca Attipoe gives a demonstration to a group of hotel employees so that they may provide female condoms to guests.

\section{Experiences of Users at SWAA and other Distribution Sites}

Although SWAA has been the most consistently active promoter of the female condom in Ghana, other provider organizations from the working group have also continued distributing the method. In interviews, staff members from these organizations and SWAA members shed light on the diversity of users' perspectives and experiences. The following discussion synthesizes reports from the various provider groups and their clients.

\section{User Profiles}

As the working group had hoped, the female condom has appealed to a diverse population in Ghana. One group of users are women whose partners are unwilling to use the male condom, but are more comfortable with the female condom. The Planned Parenthood clinic in Accra describes the typical user as a relatively educated married woman who wants to delay pregnancy, is unable to use other methods, and whose partner is unwilling to use the male condom. As one user stated: "My husband will not use the male condom. [With the female condom,] my experiences with unwanted pregnancies are over."

By contrast, other programs have found that women, particularly younger women, are using the female condom primarily to protect themselves from infection. Some women (and men) use the method only when they have an active infection, discontinuing use after treatment. Another group of users consists of women who have multiple partners, including some sex workers. As one sex worker indicated, "In situations where no condom was used, I was pricked by my conscience." In one sur- 
vey of 132 SWAA users, fear of infection was the single most important motive for use, although more than 40 percent of the respondents cited protection from infection and from unwanted pregnancy as factors (Boraas and Asante 2003).

One user group-regardless of whether their concern is about pregnancy or infection-is women whose partners object to using the male condom for a variety of reasons. The female condom has a niche where otherwise there would be no protection, which recasts the policy debate about the method. As Bernice Heloo commented, "Issues of pricing and accessibility are important. But the female condom gives many women their sole protection over their health. From a policy and program perspective, it cannot be compared with the male condom."

\section{Method Acceptability}

Many users are skeptical when they first see a female condom, but they develop comfort with it over time. As one user explained, "The female condom looks big, but it fits very well and does not feel any different from the male condom." According to several midwife-distributors, women say that men do not object to the female condom because "they are only interested in having sex. They do not even notice that it is there." Experience with other methods also shapes opinions; one man in Akim Oda reported, "I think I will use the female condom forever because, so far, it has not burst, as has happened with the male condom."

Some users report increased comfort or pleasure during intercourse. For example, the Ghana Registered Midwives Association reported that some older women use the method because the lubrication makes intercourse easier. A student commented, "I get more sensation when I use the female condom." A (male) truck driver commented, "The female condom is more pleasant... because it does not feel as tight as the male [condom]."

Of course, not all users were satisfied with the method. Those who had discontinued use did so because either they or their partner found the method unpleasant (noisy or difficult to use). Some men and women reported reduced sensation during intercourse. Others found it cumbersome and noisy, or "too big and thick." Some women have nicknamed the method "polytank," a reference to the large plastic water containers used throughout the country. One Planned Parenthood nurse explained that some women find that the outer ring of the condom can get in the way. Some users believed that the female condom is dangerous and could get stuck in the reproductive tract. Another concern was that the method could encourage promiscuity.

Some promoters have found challenging their attempts to help potential users sort through sensitive issues that affect acceptability. Even among SWAA's own member-promoters, few adopted the female condom as their own method. These women cited the same "difficulty with their husbands" that many other women reported.

\section{Tension Characterizing}

\section{Sexual Relationships}

The intrinsic characteristics of the method are not the only, or perhaps even the principal, determinant of acceptability. Rather, the social context in which sex is taking place affects method use, and many women are having sex in a context of unease or mistrust. For example, one midwife who distributes the method explained that to negotiate barrier-method use, most couples need guidance in how to initiate discussions about the intimate aspects of sex. A Planned Parenthood nurse encourages married women to "start negotiating before getting to the bedroom." Victoria Tutu, a midwife at 
Adabraka, is more pragmatic, reminding women that they can insert the condom up to eight hours before having sex, so that "If you don't trust men, you can still protect yourself."

Tutu's comment touches only lightly on the deep tensions that often characterize Ghanaian women's sexual encounters. For example, many clients need a contraceptive (and ideally, a microbicide) that they can use not only independently but surreptitiously. ${ }^{8}$ Moreover, many are hesitant to mention the method to their husbands because it brings to the surface the reality of sexual infidelity and can make either partner the object of suspicion. As one woman explained, "If the wife comes home and shows him a female condom, he's going to think, 'I'm faithful to her, and she gives me this?'"

Although the threat of conflict and violence may impede some women's ability to use the female condom, others turn to the method precisely because of the difficult circumstances that they are facing. For example, sex workers must manage thorny relationships with their clients; one nurse who provides services to sex workers reports, "If a woman sees that a man is diabolical, she will sometimes use the female condom. The female condom is good for women because sometimes men are trickish."

Providers also report that women at risk of experiencing coerced sex are using the method. One nurse commented on the challenge of facing the double threats of forced sex and a resulting disease or pregnancy. She cited the example of women firefighters who go off with male coworkers to the bush: "They go to the field with men and they know men are going to push them for sex . . . or even attack them. They say they're going to urinate and then they put in the female condom."

\section{Stumbling Blocks}

With most new temporary methods, initial interest is high as people experiment with the technology, and then settles at a much lower level that reflects ongoing use among those who find the method acceptable. The use levels in Ghana followed this trajectory. The biggest obstacle to positioning the female condom as a viable option in Ghana, however, has not been low acceptability. Rather, SWAA found its efforts mired in logistical obstacles to access-problems with supply and pricing at the national level.

\section{Securing Supplies}

From the outset, uneven supplies undermined the method's introduction. In a sense, the pitfalls of the introduction were symptoms of its own success: Enthusiasm among women-and relative disinterest in the donor worldthrew the supply system off balance.

The problems began even before the official launch of the method, when difficulty securing donor support resulted in an initial procurement that was smaller than that which the national female condom working group had anticipated. Moreover, many of the people who were being trained as distributors (by all of the participating organizations) had begun offering the method in the weeks before the national launch date; by that day, therefore, early demand had already partially depleted supplies. To avoid losing momentum when the working group was unable to find donors willing to support subsequent purchases, Moses Mukasa used UNFPA country program money to arrange for airlifting an additional but limited supply of the method to Ghana. He also met with World Bank representative Peter Harrold, who facili-

\footnotetext{
${ }^{8}$ In Northern Ghana, for example, where fewer women have access to education and where socioeconomic levels are lower than in other regions of the country, many women are reluctant to give up injectables for this reason.
} 
tated the purchase of one million female condoms for the Ghana Ministry of Health. ${ }^{9}$ Mukasa explained, "The personality of characters was important in this collaborative effort. The World Bank representative cared about AIDS."

Unfortunately, the shipment arranged by the World Bank did not arrive for more than a year. The samples intended for use as community-demonstration supplies quickly disappeared. The distributor-promoters found many women willing to use the female condom, but these women were frustrated when they could not be resupplied. In many places, women visited distribution centers to request the method, only to be turned away.

By the time new supplies arrived, the distribution system was destabilized, and many women had given up trying to obtain the method. This setback made predicting demand difficult and resulted in fewer requests leading to procurement of the next order. This lack of stability further suppressed both providers' and users' interest and threatened to spin the entire female condom delivery system into a downward spiral.

A year after the official launch of the female condom, interest in the method was beginning to wane. ${ }^{10}$ The Ghana Social Marketing Foundation, frustrated by the lack of steady supplies, abandoned its plans to add a "high-end" brand for the private sector. Planned Parenthood of Ghana provides the method but has observed that its clients often do not return; staff were unclear about the number of their clients who are restocking the method at pharmacies nearer to their homes and how many have discontinued use. At the $\mathrm{MOH}$ clinics, demand for the method had never been as high as in other sectors; counseling in the resource-poor public clinics may not have been adequate to teach women enough about the female condom so that they could imagine being able to use it successfully. The West Africa Project to Combat AIDS and STIs (WAPCAS) reported having reasonable success in promoting the method among the sex workers who are regular clients at the Adabraka Clinic.

Presently, the female condom accounts for only a small fraction of all contraceptive use in Ghana. ${ }^{11}$

Ensuring steady supplies is essential if the female condom is to develop a niche in a country. The stakeholders in promoting access to the female condomamong which SWAA is now in a leading role-must take several steps back and try to overcome the sense that the project "has slipped from sight." One important requirement is that of gradually building back demand in a manner that will allow distribution agencies to predict supply needs. National advocacy and publicity campaigns, together with a renewed investment in social marketing, are necessary for the female condom to reach its potential.

\footnotetext{
${ }^{9}$ The money for this purchase came from a fund supplied by the World Bank, the (UK) Department for International Development, the Danish International Development Agency, the European Union, and the government of the Netherlands.

${ }^{10}$ Although SWAA has no quarterly records documenting commodity flow, $\mathrm{MOH}$ and the Ghana Social Marketing Foundation records show that consumption at the public clinics and pharmacies began to level off after the first year.

${ }^{11}$ Although the majority of users still rely on hormonal methods, a very small number of Ghanaian women has adopted the female condom as their contraceptive method. Official figures for contraceptive use, however, presumably underestimate overall use of the method, because they exclude those individuals who use the method specifically, even if only briefly, for disease protection (MOH/GHS 2001).
} 


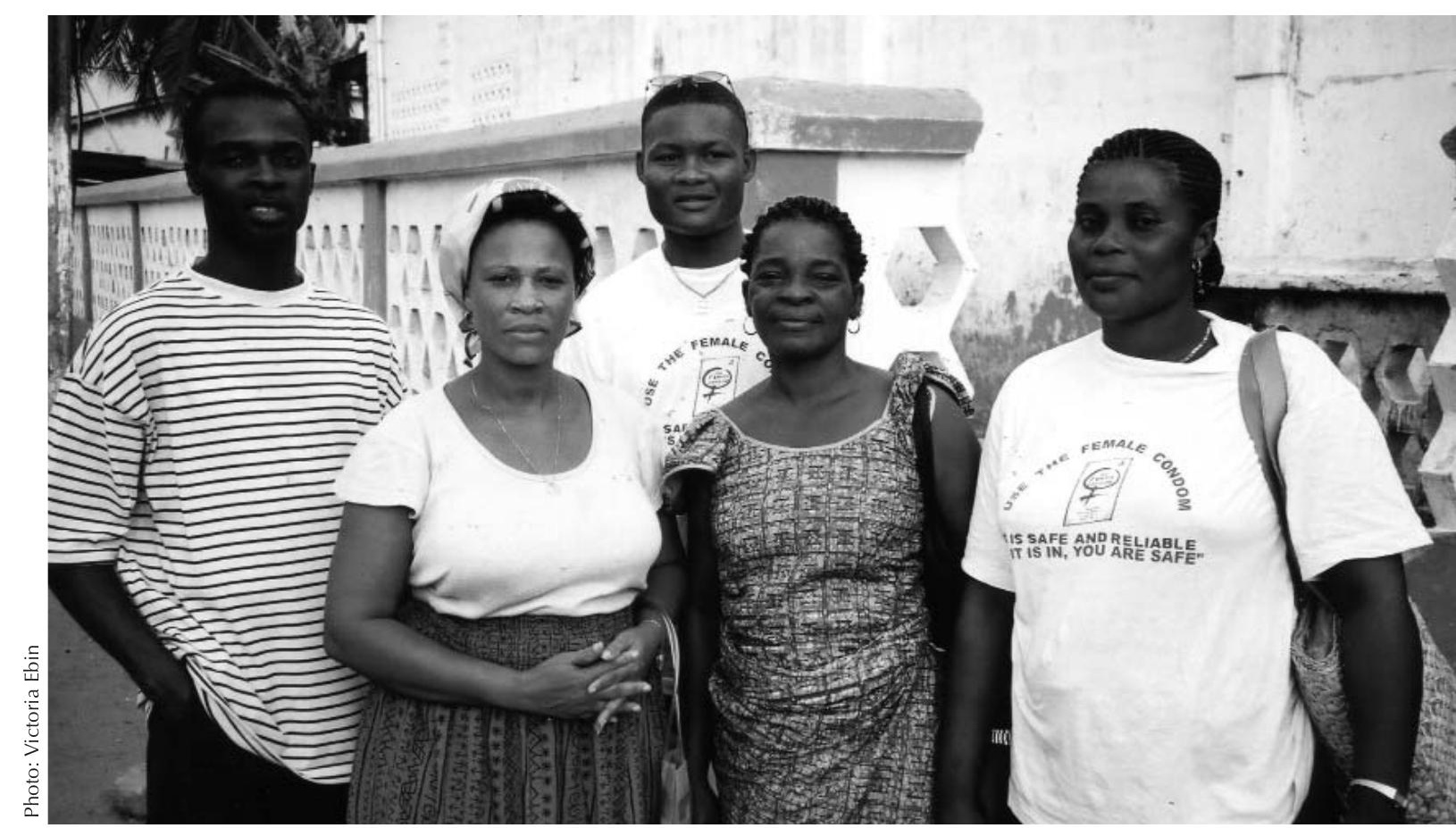

Despite the challenges, SWAA-Ghana's staff members maintain their commitment to promoting the female condom, stating that the cost is a small price to pay for reducing HIV-infection rates and empowering women.

\section{Regulating Pricing}

Pharmacies continue to sell the method, and many women who first hear about the female condom at a clinic find it more convenient to restock at a local pharmacy. Because the Ghana Social Marketing Foundation is not involved with supplying the method, no mechanism exists to regulate and enforce price controls, however.

SWAA currently sells the female condom for 300 cedis $(\$ 0.04)$, a price comparable to that of the male condom, which is sold by most providers in a set of three condoms for 900 cedis. ${ }^{12}$ SWAA is concerned, however, about the affordability of the method if the price increases. One SWAA promoter expressed concern that even the current nominal cost represents a barrier for many women:
"You need money to buy it, and some women just don't see money on a daily basis." Kathlyn Ababio, a midwife and president of the Ghana Registered Midwives Association, gives free samples to women who she feels are at elevated risk of an infection. She explains, "Infection is easier to prevent than to cure."

\section{SWA A's Institutional Challenges}

In addition to these structural problems, SWAA faces its own organizational challenges. Currently, SWAA carries out procurement, distribution, and follow-up with minimal documentation. As a result, the organization is uncertain about the number of distributors who have been trained or how they are carrying out their

\footnotetext{
${ }^{12}$ SWAA is able to purchase female condoms for $\$ 0.02$ with subsidies from the Ghanaian government and UNFPA.
} 
work. Bernice Heloo (the current president of SWAA-Ghana) explains that SWAA does not know who is buying the female condom, why they are buying it, or whether and how they are using it. The organization's leaders are hoping to develop a management information system to track and analyze commodity flow and monitor project activities at all levels.

Another goal is to strengthen the counseling skills of SWAA's promoters. SWAA's evaluation indicated that distributors often lack the capacity to foster women's negotiation and communication skills and to address such sensitive issues as infidelity and trust in marriage. To this end, SWAA is hoping to offer another training of trainers workshop to enable promoters to position the female

\section{The female condom campaign}

offered SWAA a vehicle for

revitalizing itself as an organiza-

tion. The project was providing

a relatively weak organization

with a mobilizing focus and an

opportunity to enhance its own

credibility nationally and locally.

condom not as stand-alone technology, but as a tool within an educational package. The refresher training will also address questions about reusing the female condom (see the Afterword).

The most immediate concern facing SWAA, however, is that the DANIDA funding for the female condom project (\$200,000 per year) has ended. Currently, UNAIDS funds are enabling SWAA to continue its promotion of the female condom. ${ }^{13}$ Because the organization is committed to making the method available to poor women using an intensive educational approach, distribution and sales can never provide significant revenues. To expand its coverage to the entire country, Rebecca Attipoe estimates that SWAA would require revenues of $\$ 500,000$ per year.

Some critics of SWAA's effort may express concern that such budgetary requirements are excessive. SWAA's position is that this cost is a small price to pay for reducing HIV-infection rates and empowering women.

\section{Looking Ahead}

Despite daunting obstacles to securing steady and affordable supplies, the Ghanaian experience, and SWAA's experience in particular, can well serve other countries' governments, providers, and organizations hoping to empower women by incorporating the female condom into HIV-prevention efforts. Ghana is one of the few countries that has introduced the female condom nationally through a wide range of channels. The working group members attribute their achievements to their successful collaboration. As Alice Lamptey reflected, "The right sort of partnership has been key to our success. None of us could have done it alone." Each partner brought its strength to the undertaking. UNAIDS facilitated the process and brought everyone together. UNFPA provided resources to ensure affordability. UNAIDS negotiated a reduced price from the Female Health Company. The government of Ghana made a commitment to offering women a method they could control,

\footnotetext{
${ }^{13}$ Another grant was awarded in 2003 by the Open Society Institute that enabled SWAA International to include SWAA-Ghana in a project to test strategies, strengthen collaborative networks, and generate lessons for female condom work in several countries.
} 
managing licensing and procurement, and providing the method in public family planning clinics. The NGO sector, with the capacity to provide appropriate education and counseling, took the lead in providing the method beyond clinic settings. Although this partnership was eased by the fact that many members of the group had previously established professional relationships, their shared commitment to enabling women to save their own lives was what gave the working group its vitality.

Over the long haul, however, SWAAGhana carried the project into villages across the country. In doing so, the organization approached its work not as commodity distribution but as an education and empowerment campaign. Despite the remaining challenges, their efforts to date have reconfigured the work of preventing HIV transmission across the country and have provided lessons for the field about how to view distribution of technologies related to sexuality and gender.

Moreover, the female condom campaign offered SWAA-Ghana a vehicle for revitalizing itself as an organization. The project was providing a relatively weak organization with a mobilizing focus and an opportunity to enhance its own credibility nationally and locally. It enabled the organization to build its grassroots base, to strengthen its affiliation with religious groups, and to cultivate a relationship with the media. The campaign provided a vehicle for extensive institutional development, because SWAA was forced to reckon with its own internal strengths and weaknesses in order to develop its capacity in training, in developing materials, in management information systems, and in monitoring program activity. Finally, through its collaboration with SWAA International on the Women's Protection Initiative, SWAA-Ghana raised its

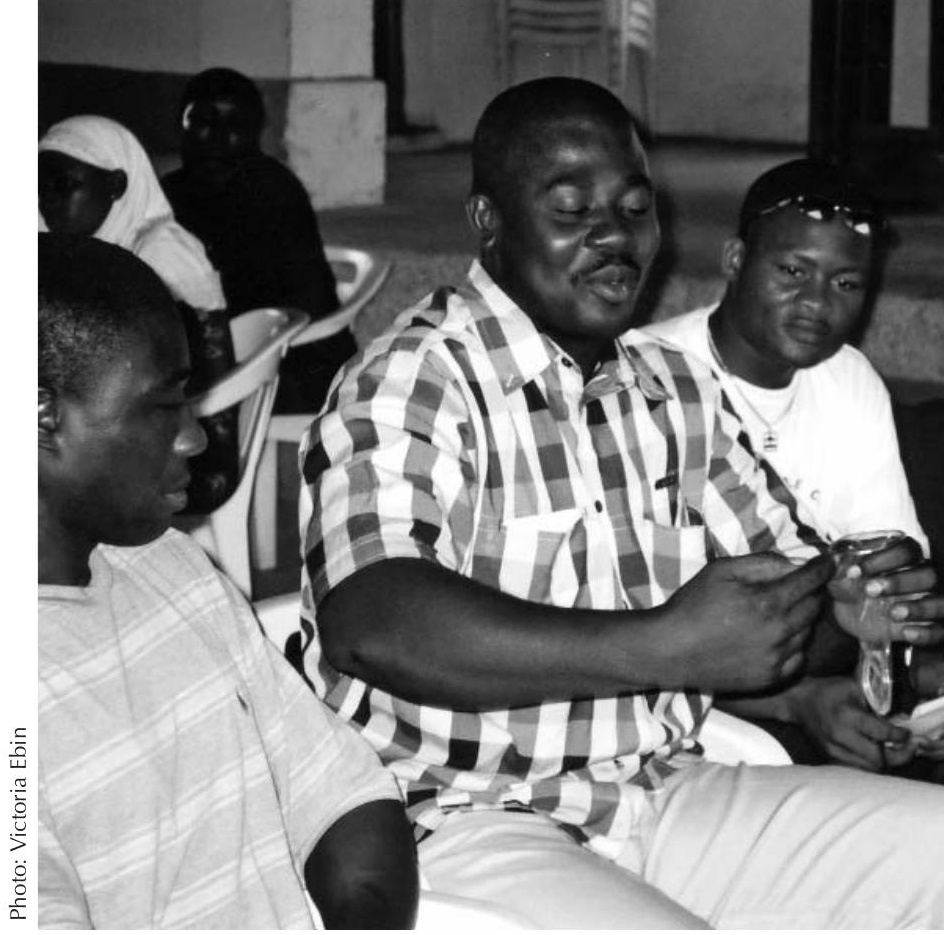

As SWAA-Ghana carries the female condom project forward, they continue to emphasize the importance of engaging men.

profile and helped to generate networks and lessons across the region.

Sorting out problems of commodity logistics-including pricing and supply-is not easy. It will demand even greater commitment and creativity to implement programs that-reflecting emerging policy mandates-seek to change power relations between males and females in family life, schooling, employment, policymaking, and other dimensions of daily life that shape sexual decisionmaking. Echoing some of the most far-reaching community healthpromotion drives, SWAA-Ghana's experience illustrates how an NGO must help create women's social capacity to use the very technology it is distributing.

The organization's leaders hope to secure enough funding to enable SWAAGhana to scale up nationally, working in partnership with the government to secure supplies. As Alice Lamptey says: "I'm sold on NGOs and what they can do. I believe in NGOs. [With more] support . . . we could do more." 


\section{Experiences from Other Countries}

The experience in Ghana is unusual both because of the level of multisectoral collaboration and because a women's NGO became the leading local distributor of a new technology. In an effort to deliver the female condom to women as quickly as possible, the Ghanaian team had decided to compromise on the degree of research and documentation associated elsewhere with the introduction. In other countries, the pro- cess-involving different models-has been more closely studied, and these experiences have generated their own lessons for the field. Brief summaries below describe the process of introducing the female condom in three countries (Brazil, South Africa, and Zimbabwe) in which the government maintained a more ongoing active role than in Ghana in making the female condom available to its citizens.

\section{Brazil: Feminist Perspectives Penetrate the State Apparatus}

As a result of the strong influence of the Brazilian feminist movement, the Ministry of Health approached the female condom already sensitized to the way in which gender issues affect contraceptive use and HIV-prevention efforts. For years, feminist organizations have provided input to state commissions on issues of quality of care and women's rights. Indeed, both the National AIDS Program and the National Women's Health Program within the Ministry have feminist leadership. When the female condom became available, the $\mathrm{MOH}$ quickly responded with a large-scale acceptability trial (conducted by the University of Campinas and involving 2,400 participants) to determine if the female condom would help to fill the gap in HIV-protection mechanisms for women in Brazil.

Acceptability rates exceeded expectations: 93 percent of the women tried the female condom and 76 percent of them continued to use it, yielding a 70 percent acceptability rate. Study participants reported using some form of protection during intercourse 65 percent of the time, compared with 31 percent before they entered the study. These results encouraged the government to proceed with a national distribution campaign. The campaign began in October 1999, and the Ministry allocated $\$ 1.28$ million for the program per year. They expected to provide two million female condoms for 25,000 women.

Because the introduction research also found that acceptability rates were elevated when users were contacted through community-based distribution, the $\mathrm{MOH}$ developed strong partnerships with NGOs that could provide necessary community outreach. To reach high-risk groups, some of the NGOs were selected for their particular ability to reach sex workers and HIV-positive women and their partners.

The Ministry of Health selected 340 programs (health services and educational and advocacy groups) to distribute the female condom. Train- 


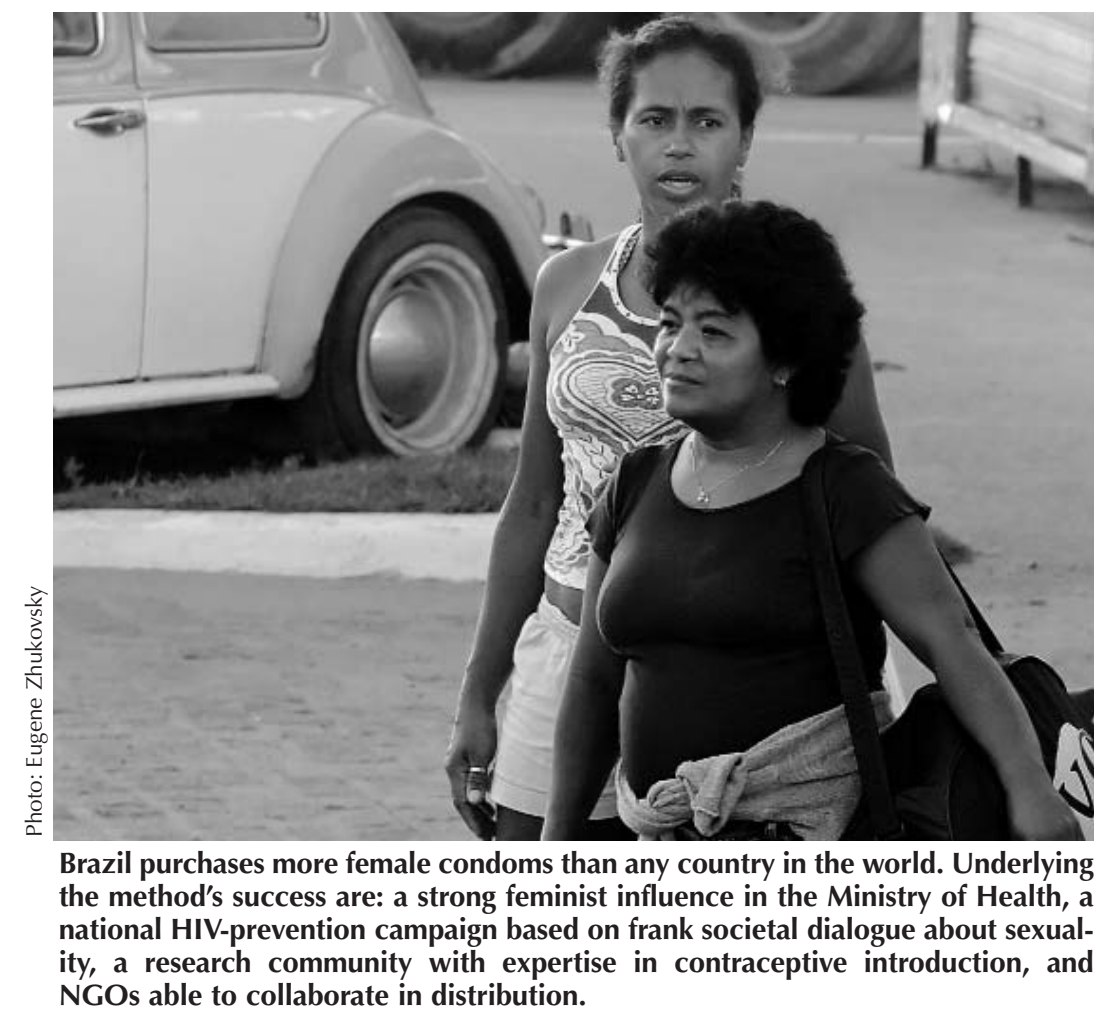

ing was provided for three professionals from each program. Topics covered in training included sexuality, gender roles, myths, taboos, sexual practices, dual-method protection, and self-esteem. The two-day training sessions were followed by an observation period. The $\mathrm{MOH}$ also designed educational awareness sessions for female users.

Thanks to well-developed projections of demand, strong ideological commitment within the public sector, and (relative to African countries) adequate resources, Brazil's $\mathrm{MOH}$ has been able to ensure that female condoms are consistently available at no cost in many locations throughout the country. From 2000 to 2002, the $\mathrm{MOH}$ ordered more than eight million

female condoms for free distribution. As distribution has increased, the number of participating NGOs has also increased each year to reach more users. In addition to the government's free distribution, female condoms are sold through DKT do Brazil, a social marketing organization that had launched a female condom dissemination campaign for World AIDS Day as early as 1997.

By 2002, the female condom was available at 417 locations across Brazil. $^{14}$ The government and its partner NGOs continue to study female condom use in an attempt to overcome barriers and to reach women who are at risk and who lack the power or skills to insist that their partners use the male condom.

\footnotetext{
${ }^{14}$ Currently, taxes and embargoes in Brazil threaten the security of female condom supplies.
} 


\section{South Africa: A Joint Introduction of the Female Condom and Emergency Contraception}

In South Africa, the government introduced the female condom in tandem with another new technology: emergency contraception. This initiative responded to a 1994 assessment of existing reproductive health services, which found that women had severely limited contraceptive choice. In 1998, with the goals of improving quality of care and increasing the options available to prevent transmission of HIV and other STIs and to prevent unwanted pregnancies, the National Department of Health launched the National Introduction of the Female Condom and Emergency Contraception.

In deciding how to position the female condom, the National Department of Health, working with the Reproductive Health Research Unit (RHRU) of the University of Witwatersrand, involved providers who served different populations throughout the country. The plan called for free distribution of female condoms to clients in 31 pilot clinics (both government and Planned Parenthood sites) and to sex workers, and for subsidized distribution through the private sector. Health Department provincial coordinators (seven nurses and one public health officer) were selected to monitor staff at clinic distribution sites, provide them with support, and collect data.

A series of three-day trainings focused on counseling and logistics related both to the female condom and to emergency contraception.
Although clinic staff were the main participants, providers to the sexworker community, the provincial coordinators, and several additional trainers also attended the workshops.

Each clinic received an initial supply of 3,000 female condoms and was required to file reports on their distribution in order to receive more. In the first 18 months of the program, 9,406 government clinic clients and 1,381 Planned Parenthood clients took female condoms home to try. These clients were predominantly women aged 20-29 who continued to use hormonal contraceptives. Nearly 14 percent of these women returned for additional supplies. This proportion is considered an underestimate of actual continuation, however. Some sites experienced shortages of forms and, therefore, failed to report on distribution fully. Moreover, Planned Parenthood staff reported that some women found restocking more convenient at local pharmacies or gas stations participating in the pilot study.

For distribution to sex workers, the government worked through the Sex Worker Advocacy Task Force (SWEAT). SWEAT serves 4,500 sex workers on the streets and in massage parlors and those affiliated with escort services. In the first 18 months, SWEAT distributed 11,698 female condoms, despite a three-month gap during which time the supply dried up.

To establish private-sector distribution, the Health Department pur- 
chased 150,000 female condoms and donated them to the Society for Family Health (SFH) to be sold in packages of two under the brand name care at pharmacies, gas stations, and spaza shops (convenience stores). SFH sold care for R4.25 (\$0.32 in 2000), half the recommended retail price (Bank of Canada 2005). In the first year, more than 20,000 female condoms were sold at

\section{Based on the success of}

the pilot, the government

increased the number of

distribution sites to

include primary health-

care services, hospitals,

services for sex workers,

truck-stops, workplaces,

NGOs, and youth centers.

590 locations. Two provinces (Guateng and Kwazulu-Natal) accounted for most of these sales, however care remained virtually unavailable in four rural provinces.

The RHRU, working in collaboration with Family Health International (FHI), provided technical assistance, particularly in monitoring the progress of the introduction. For the performance evaluation, the RHRU interviewed 39 public-sector providers and 198 women who had received the female condom at least once. Of the 177 who had ever used it for sexual intercourse, 32 percent had used it three or fewer times, 33 percent had used it four to ten times, and 35 percent reported using it more than ten times. Some women used female and male condoms interchangeably, resulting in greater overall method use. Of the 86 women who had used the female condom in the month prior to their interview, 38 had also used the male condom. Eighty-eight percent reported that, overall, they used protection more often than they had before the female condom was available to them, and 93 percent said they might purchase the female condom if it were not available for free. Almost all women (96 percent) recalled that a provider had given them instructions and a demonstration when they first received the method.

Distribution varied considerably among clinics. Low distribution rates were associated with staff turnover, specifically with the departure of providers who had attended the training. The RHRU recommended formalizing the transfer of information to other staff and fostering efforts to reach men to increase method acceptability.

Based on the success of the pilot, the government increased the number of distribution sites, to a total of 204 sites by late 2005, including primary health-care services, hospitals, services for sex workers, truck-stops, workplaces, NGOs, and youth centers. The gradual introduction of the method has fostered steady increases in use, and South Africa has become the one of the largest consumers of female condoms in the world. Plans are evolving for continued expansion of the method's availability. 


\section{Zimbabwe: After a Meteoric Jump and Early Falloff, Use Continues to Outstrip Projections}

In Zimbabwe, various governmental bodies have been actively involved in licensing, pricing, distribution, and direct provision of the female condom. The government's involvement began in 1994, when representatives from the National AIDS Coordination Programme and Zimbabwe National Family Planning Council (ZNFPC) met with researchers from the University of Zimbabwe to discuss the results of a WHO-funded acceptability study of the female condom. The study was conducted with diverse populations, and participants were divided into four groups: rural, urban, and two groups of sex workers. At least 66 percent of respondents from each group preferred the female to the male condom. In the rural and urban groups, 82 percent were married women, many of whom were at risk of acquiring HIV infection from their husbands but were unable to convince them to use a male condom.

Several steps had to be taken before distribution could begin. First, the government's Medical Control Council had to approve the device, which required that a plan be developed for making the method available to women at an affordable price. Several more years passed in dialogue to establish this plan; this process engaged the government agencies, UNAIDS, and the Women and AIDS Support Network (WASN), a Zimbabwean NGO to which the original university researchers also belonged.

WASN simultaneously carried out a media campaign and communitymobilization effort that culminated in a petition carrying 30,000 signatures presented to the government on World AIDS Day in December 1996. The Minister of Health agreed to offer his sup- port, and by September 1996, the Medical Control Council had approved the female condom for use.

Once the method was approved, the government undertook the marketing campaign, in collaboration with Population Services International (PSI). This campaign folded the introduction of the female condom into a male condom promotion campaign supported by British and US aid programs.

To enable married women to negotiate method use without raising sensitive questions about disease and infidelity, the introduction emphasized the female condom's contraceptive function. To further differentiate between the male and female condoms, the method was renamed as a "contraceptive sheath" under the brand name care.

Key decisions had to be made regarding pricing. Funds were secured to further subsidize the UNAIDS-negotiated price $(\$ 0.63)$, allowing for a user price of $\$ 0.15$ per condom.

To ensure that staff would be available to provide instructions for care's use, sales locations were initially limited to clinics and pharmacies. PSI sent trainers to visit the pharmacies, public clinics, and pharmaceutical wholesalers to provide them with educational materials. Over time, supermarkets, hair salons, and other locations were allowed to carry the female condom. The government and PSI forecasted that a realistic goal was to sell 80,000 condoms during their first year on the market.

In response to the marketing campaign and to women's desperate need for protection against HIV, initial sales far exceeded expectations: 106,000 female condoms were sold during the first four months alone. Unfortunately, donor support was not adequate to main- 
tain consistent supplies, and the method's availability declined rapidly. The resulting instability of supply, combined with the leveling off that typically follows an elevated initial interest in a new method, caused sales to drop by 53 percent during the second half of the year.

Although some observers viewed this sharp leveling off as evidence that the introduction of the female condom had largely failed, in fact, the ongoing use levels continued to outstrip initial projections despite uneven supplies. Indeed, even with the decline, more than two times the anticipated number of female condoms were sold in the first year of the program (Kerrigan et al. 2000).

By late 2002, because of the faltering Zimbabwean economy, combined with lack of donor support, the user price had risen dramatically — to $Z \$ 27.50$ (\$0.51) per condom (the male condom was sold at that time for about onethird that amount and was available for free at many sites). Some women, particularly sex workers, reported that the higher prices were forcing them to re- use the female condom in multiple sexual encounters (WASN 2002). (See the Afterword for a discussion of reuse.)

As part of a government-sponsored program to improve availability, PSI turned to hairdressers in 26 salons in Harare and Mutare to help distribute care. Hairdressers, who often have a relaxed personal relationship with their clients, were trained by PSI in the correct use of the method and in negotiation techniques that they could teach women to use with their partners. The hair-salon program also generated renewed attention to and media coverage of the female condom.

Currently, ZNFPC is trying to restabilize supplies and use of the female condom. The Council is now the focal point for free distribution, relying on 1,280 ZNFPC and government clinics, as well as 435 community-based distributors. Following a 2005 situation analysis, ZNFPC (with assistance from UNFPA and JSI/Europe) is also working to establish a single strategic plan for both the male and female condom.

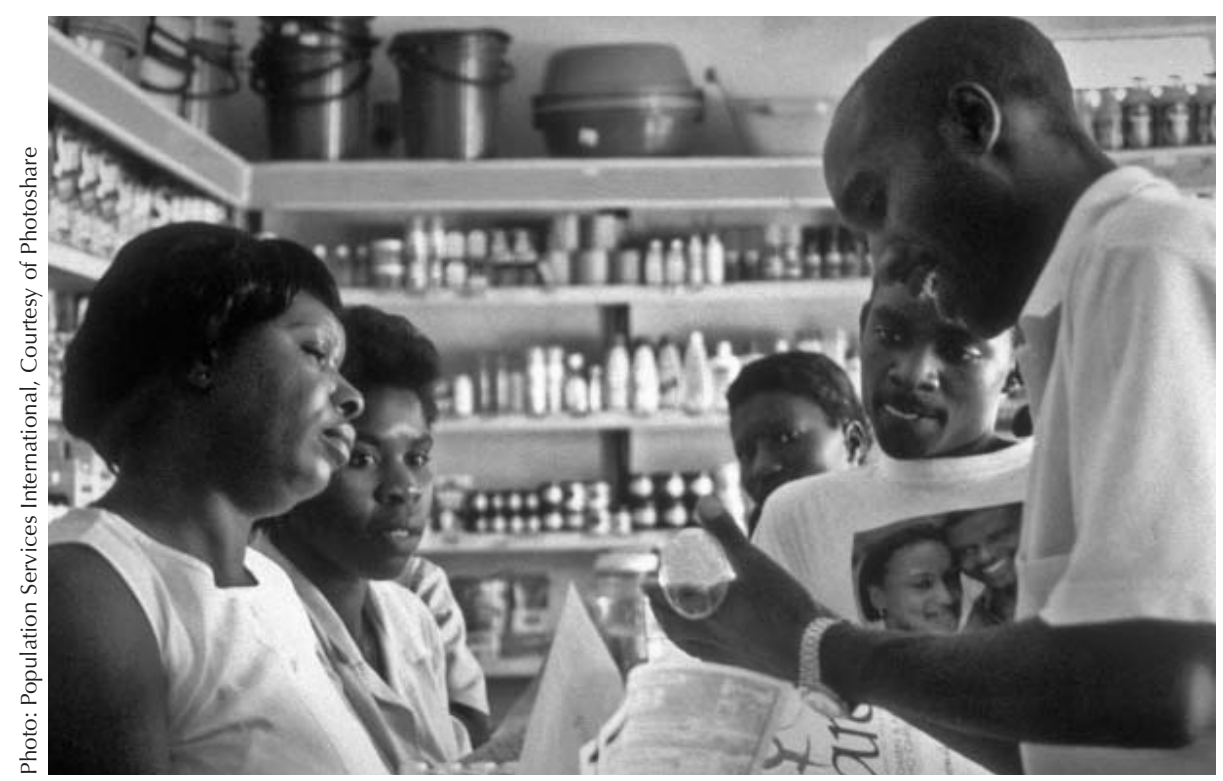

To ensure that staff would be available to provide instructions for use, sales locations were initially limited to clinics and pharmacies. Initial sales far exceeded expectations: 106,000 female condoms were sold during the first four months alone. 


\section{Lessons Learned}

Across the globe, efforts to enable women to protect themselves against infection and unwanted pregnancy have generated similar lessons. Some of the most important lessons learned from female condom programs in Brazil, Ghana, South Africa, and Zimbabwe are:

- The female condom has a real-and fairly heterogeneous-potential user population. To reach this target audience, however, the method may have to be positioned initially as a contraceptive with additional benefits of protection against disease rather than being targeted to sex workers as the primary users.

- Distribution of a method such as the female condom depends on a structure for providing education and counseling about sexuality, power in intimate relationships, and fears of HIV infection. From a planning perspective, the technology is almost secondary to facilitating this interpersonal exchange.

- Government, social marketing agencies, and NGOs all have roles to play in introducing the female condom. NGOs, and women's groups in particular, may be best suited to organize and foster the discussions that surround initial distribution and promotion of the female condom. Pharmacies, however, are often the most convenient site for some women to obtain resupplies of the method, although wide-scale distribution through pharmacies will depend on continuing subsidies.

- The comparison with male condoms — which women cannot use and which men often will not use-is a spurious one, financially as well as programmatically. If women who are learning that they have the right to protect their own lives are going to be able to secure the means to do so, international donors and, where feasible governments, must invest in large enough procurements to lower the method's unit cost and to avert crises in supply and demand.

\section{References}

Akai-Nettey, Regina. 2003. Personal communication.

Boraas, Christy and Lydia Asante. 2003. Evaluation of the SWAA-Ghana Female Condom Promotion Project. Accra: Prolink.

Ghana Social Marketing Foundation (GSMF). 1999. Pricing Study on the Female Condom Report. Report submitted to the Ministry of Health on behalf of the Female Condom Working Group.

Ghana Statistical Service (GSS) and Macro International (MI). 2000. Ghana Demographic and Health Survey 1998. Calverton, MD: GSS and MI.

Ghana Statistical Service (GSS), Noguchi Memorial Institute for Medical Research (NMIMR), and ORC Macro. 2004. Ghana Demographic and Health Survey 2003. Calverton, MD: GSS, NMIMR, and ORC Macro.

Glasgow, Muriel. 2001. "Promotion of the female condom: Where we came from; where we are; where we're going." UNAIDS Case Study. Geneva: UNAIDS.

Kerrigan, Deanna, Steve Mobley, Naomi Rutenberg, Andrew Fisher, and Ellen Weiss. 2000. The Female Condom: Dynamics of Use in Urban Zimbabwe. Washington, DC: Population Council.

Ministry of Health (MOH) and Ghana Health Service (GHS). 2001 Annual Report. Accra: MOH/GHS Reproductive and Child Health Unit, Public Health Division.

National AIDS/STI Control Programme (NACP). 2001. HIV/AIDS in Ghana: Background, Projections, Impacts, Interventions, and Policy. Third edition. Accra: Disease Control Unit, Ministry of Health.

UNAIDS and WHO. 2000. The Female Condom: A Guide for Planning and Programming. Geneva: UNAIDS and WHO.

World Resources Institute (WRI). 2003. "Food and Agriculture: Ghana" Earthtrends Country Profiles. Washington, DC:WRI. <http://earthtrends.wri.org/pdf_library/country_profiles/agr_cou_288.pdf>. Accessed 15 December 2005. 


\title{
Afterword
}

\author{
by Martha Brady
}

As we enter the third decade of the HIV/AIDS pandemic, the female condom is the only means by which women can take protection against STIs, HIV, and unwanted pregnancy into their own hands. The preceding case study documents the importance of government-NGO alliances that can bring the method to women at the grassroots level and enable them to protect themselves and their partners. If, however, we are to stem the tide of the pandemic, women need an expanded array of and easier access to such products. Program designers must recognize the diversity of potential users of the female condom and incorporate that understanding into their marketing, product positioning, and distribution channels and mechanisms. Moreover, we must seize the opportunity that the female condom presents to build a platform for the introduction of future HIVprevention products.

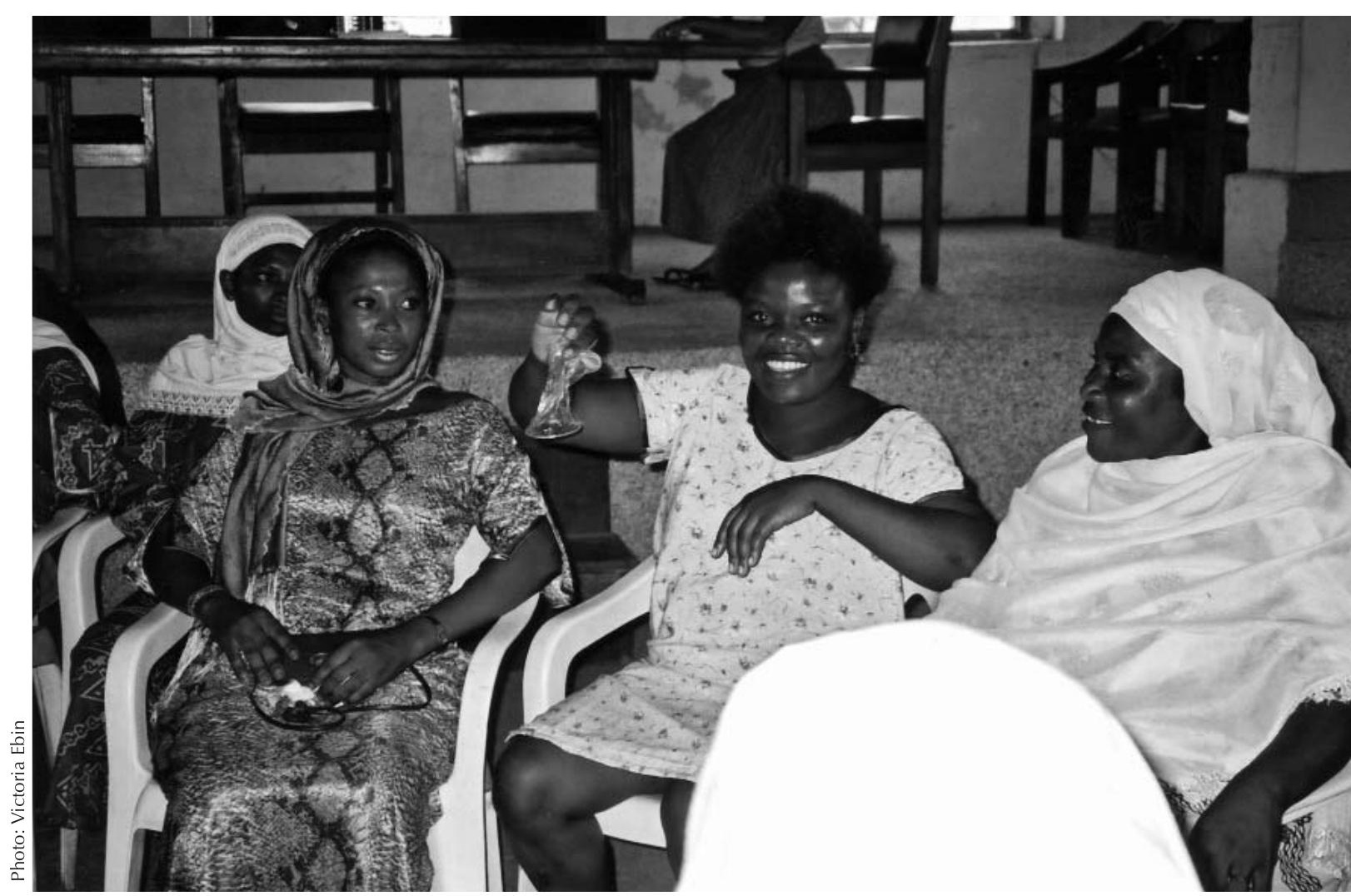

The female condom is the only means by which women can take protection against STIs, HIV, and unwanted pregnancy into their own hands. 


\section{Technology}

\section{Matters}

One avenue for moving forward is in the arena of technology. For example, ongoing debates about reuse of the female condom will affect the affordability and accessibility of the method. ${ }^{15}$ Refinements to existing infectionprevention products and acceleration of new products (for example, new female condoms, cervical barriers, and microbicides) are also promising. For example, the Female Health Company intends to launch a secondgeneration female condom; the "FC2" is expected to reduce the "noise" effect often cited as a drawback of the current product. Moreover, new manufacturing processes and a change in manufacturing locale are expected, ultimately, to drive down the price of the FC2.

Other investments in user-controlled technologies also are underway: Modified female condoms of different materials produced by means of new manufacturing processes are being designed and tested. The diaphragm's effectiveness against HIV infection is also being studied. We know, however, that no single technology will provide an answer for all women. Currently, the female condom remains the only female-initiated device that provides effective simultaneous protection against STIs, HIV, and unwanted pregnancy.

\section{But the Major Need is for a New Programmatic Wave}

While scientific development continues, the promotion of currently available technologies must advance with a renewed sense of urgency and with a bolder approach to programming. In many settings, the approach to offering the female condom has fallen into stand-alone "take it or leave it" interventions that have resulted in lowerthan-anticipated levels of acceptability and uptake. As the previous case studies demonstrate, rather than implement this narrow vision, we must identify ways to create synergies among programs through experimentation with innovative and integrated service models, venues, providers, and messages. Such initiatives can also pave the way for the introduction of future prevention technologies.

Female condom introduction must move beyond "projects" to large-scale programs. In this regard, the method must be incorporated into overall country programs and bilateral and multilateral (for example, UNFPA) plans. Due attention must also be given to the female condom in the Reproductive Health Commodity Security assessments underway in many countries. Success will require a commitment to overcoming political, economic, and social barriers.

\footnotetext{
${ }^{15}$ WHO convened a consultative process to consider the advantages and risks associated with washing and reusing the female condom. As of December 2005, WHO recommends, "the use of a new male or female condom for every act of sexual intercourse where there is risk of unplanned pregnancy or of acquiring a sexually transmitted infection (STI), such as HIV. Recognizing the urgent need for riskreduction strategies for women who cannot or do not access new condoms, the consultation developed a draft protocol for safe handling and preparation of female condoms intended for reuse." For more information, see <http://www.who.int/reproductive-health/stis/reuse.en.html $>$.
} 
The female condom must be made available by means of a range of health and nonhealth systems, both public and private. Such a diverse strategy has both practical and political appeal. Some particularly promising ideas are described below:

The female condom could be effectively positioned as an integral part of HIV prevention, care, and treatment strategies. Some approaches to be tested include:

- The provision of female condoms as part of counseling within antiretroviral treatment (ART) programs, particularly in countries where such programs are being scaled up.

- The provision of the female condom to women in serodiscordant couples identified through voluntary counseling and testing programs and through mother-to-child transmission-prevention programs.

- The positioning of female condoms as a "care" product for HIV-positive women.

Because in some settings, marriage may increase young women's risk of acquiring STIs, including HIV, intensi- fied efforts are needed to destigmatize condom use and disease protection within marriage. Field efforts can generate important lessons about reshaping the image of condoms to represent respect for health and future fertility rather than distrust or infidelity, and about reorienting antenatal care services to include protection messages and female condom distribution as needed.

The female condom can be presented as a product intended to safeguard future fertility and improve vaginal health, especially where the social significance of infertility is profound. Provision of the method should be an integral part of STI-prevention efforts.

Finally, addressing deep-seated gender inequalities is central to any serious protection strategy. Indeed, efforts to introduce the female condom and other infection-prevention methods must be carried out in tandem with initiatives to reconfigure the power dynamics between partners and the communication between men and women. Undoubtedly, such broad social initiatives must reach men as well as women.

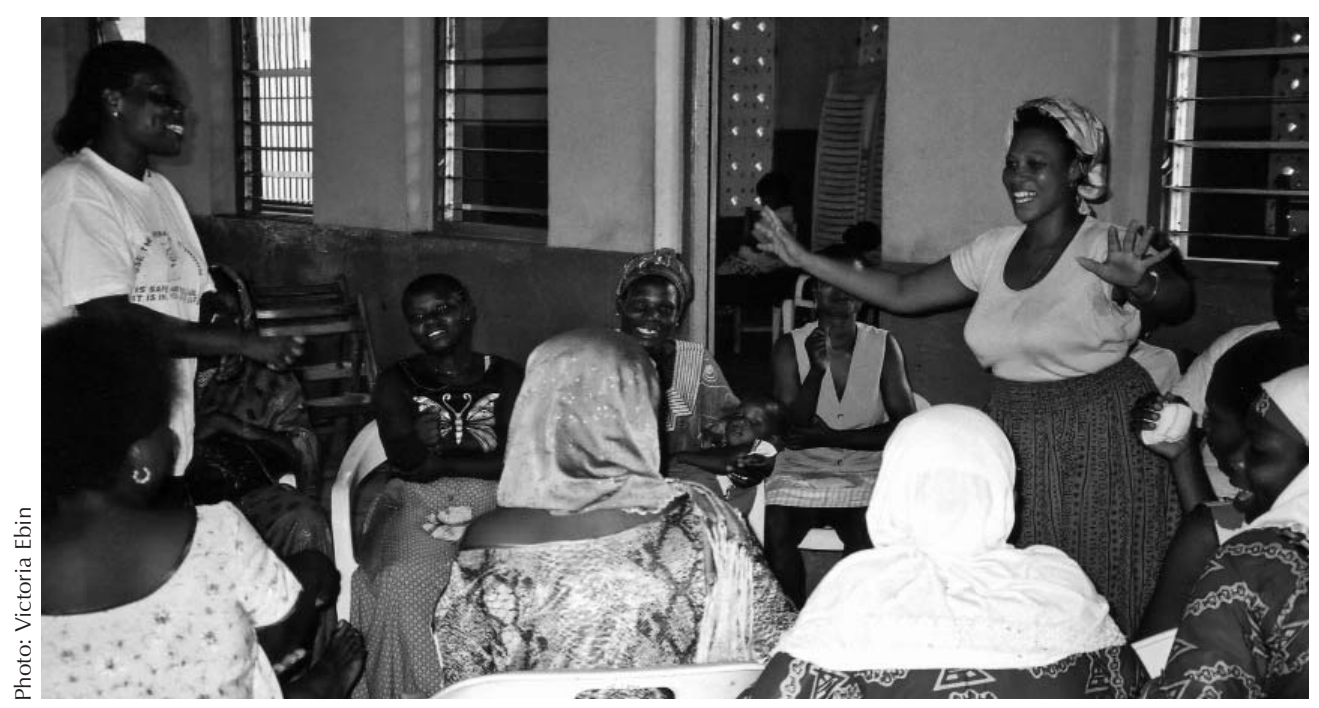

Addressing deep-seated gender inequalities is central to any serious protection strategy. Efforts must be carried out in tandem with initiatives to reconfigure the power dynamics between partners and the communication between men and women. 
A diario, mujeres y niñas contraen VIH porque no pueden lograr que los compañeros con los que mantienen relaciones sexuales utilicen condones. El condón femenino es el único medio de protección cuyo uso es iniciativa de las propias mujeres. Hasta la fecha, muy pocos países cuentan con experiencia amplia en la promoción del condón femenino, por lo tanto esos esfuerzos aportan lecciones valiosas para las estrategias de protección de VIH.

Este artículo describe los esfuerzos de la filial en Ghana de SWAA (siglas en inglés de la Sociedad para las Mujeres y SIDA en África). SWAA-Ghana fue invitada a participar en un comité multisectorial cuyo fin era ayudar a introducir el condón femenino en dicho país. SWAA insistió para que el comité redujera drásticamente el precio a las usuarias, lideró los talleres para capacitadores-de-capacitadores y, más adelante, y se convirtieró en el distribuidor principal de condones femeninos en Ghana.

El enfoque de SWAA para la introducción del producto dió un vuelco total a la distribución tradicional de productos: en lugar de centrarse en los detalles del método, el objetivo de SWAA fue convencer a las mujeres sobre su derecho a proteger sus propias vidas y facilitarles los conocimientos necesarios para la negociación del ejercicio de esos derechos, con una tecnología a su disposición. Con su dedicación a este objetivo, la organización, que carecía de experiencia en distribución de productos y hasta entonces había funcionado sin personal remunerado o proyectos de importancia, hizo llegar el condón femenino a las mujeres en todo Ghana.

Más de 80 socias de SWAA reclutaron y capacitaron a mil personas para la distribución del condón femenino en sus propias comunidades. En el contexto de conversaciones francas sobre sexuali- dad, reproducción y poder en las relaciones hombre-mujer, los distribuidores encontraron con un enorme interés sobre el método. Aunque el énfasis en la función anticonceptiva del método era importante para su imagen, la mayoría de las mujeres lo utilizaban, al menos en parte, como protección contra infecciones. Algunas mujeres informaron que sus parejas se habían negado a utilizar condones masculinos pero estaban dispuestos a utilizar el condón femenino.

La introducción del condón femenino ha tenido sus problemas. La dificultad mayor ha sido mantener su abastecimiento continuo. Los donantes vacilaron a la hora de hacer pedidos y facilitar un producto relativamente caro. Cuando el abastecimiento se hizo poco fiable, muchas usuarias que se habían mostrado satisfechas se vieron frustradas y dejaron de utilizar el método, a consecuencia de lo cual la operación perdió el impulso inicial. SWAA reconstruye ahora la demanda de forma gradual al tiempo que garantiza un abastecimiento más confiable.

Lecciones incluyen lo siguiente: 1) La población usuaria potencial del condón femenino es heterogénea pero, para evitar el estigma conectado a VIH, podría ser importante presentar el método como un anticonceptivo; 2) Las ONG serían las más adecuadas para ofrecer la educación (sobre sexualidad, problemas de género, y temor a VIH) clave para la distribución de este método; y 3) Los donantes deben invertir en adquisiciones más voluminosas del producto si se desea que las mujeres tengan acceso a esta tecnología tan importante.

La próxima edición de programación podría considerar estrategias tan innovadoras como presentar este método como un producto para salvaguardar la fertilidad futura, y intentar borrar el estigma de la protección dentro del matrimonio. 


\section{Résumé en Français}

Chaque jour, des femmes et des jeunes filles contractent le $\mathrm{VIH}$, impuissantes qu'elles sont à imposer le préservatif à leur partenaire sexuel. La seule méthode de protection dont I'usage peut être contrôlé par les femmes elles-mêmes est le préservatif féminin. Peu de pays disposent à ce jour d'une vaste expérience de la promotion du préservatif féminin. Les leçons tirées de leurs initiatives en sont d'autant plus précieuses à l'élaboration de stratégies de prévention utiles à la lutte contre le VIH.

Cet article décrit les efforts de la branche ghanéenne de I'organisation SWAA (Society for Women and AIDS in Africa/Association pour les Femmes Africaines contre le SIDA). Invitée à se joindre à un groupe multisectoriel chargé de l'introduction du préservatif féminin dans le pays, SWAA-Ghana a insisté sur une réduction considérable du coût de la méthode aux utilisateurs et pris la tête des ateliers nationaux de " formation des formateurs », devenant bientôt le principal organisme de distribution du préservatif féminin au Ghana.

L'approche adoptée pour l'introduction de la méthode a révolutionné le mode de distribution traditionnel : plutôt que de se concentrer sur les détails de la méthode, SWAA a cherché à convaincre les femmes de leur droit de protéger leur propre vie et à les initier, technique en main, aux principes élémentaires de la négociation, pour les rendre aptes à exercer ce droit. Vouée à ce nouvel objectif, I'organisation, qui n'avait alors aucune expérience de la distribution de produits et avait jusque-là opéré sans effectifs salariés ni projets de vaste envergure, a apporté le préservatif féminin aux femmes du Ghana.

Plus de 80 membres de l'organisation ont recruté et formé 1000 personnes chargés de distribuer la méthode dans leurs propres communautés. Dans le contexte de la discussion franche des questions de sexualité, de procréation, et de pouvoir au sein des relations entre les hommes et les femmes, ces agents de distribution ont découvert un profond intérêt pour la méthode. La fonction contraceptive du préservatif $\mathrm{a}$, certes, été soulignée pour son image, mais la majorité des utilisatrices ont adopté la méthode, en partie du moins, pour se protéger contre le risque d'infection. Certaines ont même déclaré que leur partenaire, bien qu'ayant refusé le préservatif masculin, s'était montré disposé à en accepter la version féminine.

L'introduction du préservatif féminin ne s'est toutefois pas déroulée sans difficultés. Le plus gros problème aura été l'assurance d'approvisionnements continus. Les donateurs se sont montrés hésitants à commander et entretenir des stocks d'un produit relativement onéreux. Face à l'approvisionnement peu fiable, beaucoup d'utilisateurs sinon satisfaites ont fini par abandonner la méthode et la campagne a perdu son élan. SWAA s'efforce aujourd'hui de rétablir progressivement la demande, tout en cherchant à assurer une réserve plus stable.

Leçons tirées : 1) Le préservatif féminin peut intéresser une population utilisateur potentielle hétérogène mais, pour éviter la connotation négative associée au VIH, il peut être important de présenter la méthode parmi les contraceptifs ; 2) les ONG pourraient bien être les mieux placées pour assurer l'éducation (sur la sexualité, les questions de genre et la peur du VIH) essentielle à la distribution de la méthode ; et 3) les donateurs doivent investir dans de plus vastes sources d'approvisionnement si l'on veut assurer l'accès des femmes à cette importante technique.

Il pourra être utile aussi, lors de la prochaine vague de programmation, d'envisager les stratégies innovatrices de positionnement de la méthode en tant que produit apte à préserver la fécondité à venir et de banalisation de la protection au sein du mariage. 


\section{About the Authors}

Martha Brady (Afterword) is a Program Associate with the Gender, Family, and Development Program of the Population Council.

Kathleen Cravero (Introduction) is Chair, Leadership Council of the Global Coalition on Women and AIDS, established by UNAIDS in 2004.

Victoria Ebin (Coauthor) is an anthropologist and consultant who works with the media in Africa and the Caribbean on improving coverage of reproductive health.

Michelle Skaer (Coauthor) is a Staff Assistant with the Gender, Family, and Development Program of the Population Council.

\section{Acknowledgments}

In acknowledgement of their valuable input, the authors wish to thank the following individuals (listed in alphabetical order): Henriette Ahrens, Rebecca Attipoe, Mags Beksinksa, Cira Endsley, Suzanne Fischer, Theresa Hatzell Hoke, Bernice Heloo, Alice Lamptey, Mary Ann Leeper, Simone Martins, Maria José de Oliveira Araújo, Beth Robinson, Mitchell Warren, and Ellen Weiss, as well as representatives of the Planned Parenthood Association of Ghana, the United Nations Population Fund Ghana office, the Ghanaian Ministry of Health, the Ghana Registered Midwives Association, the UNAIDS Ghana office, and the Ghana Social Marketing Foundation.

We invite your comments on Quality/Calidad/Qualité. If you would like to be included on our mailing list, please send an e-mail to: qcq@popcouncil.org. Most past editions are available online at $\langle w w w$.popcouncil.org/publications/qcq/default.htm $>$. Single or multiple print copies of past editions may be ordered by e-mail.

No. 1 Celebrating Mother and Child on the Fortieth Day: The Sfax Tunisia Postpartum Program, 1989. (E)

No. 2 Man/Hombre/Homme: Meeting Male Reproductive Health Care Needs in Latin America, 1990. (E,S)

No. 3 The Bangladesh Women's Health Coalition, 1991. (E)

No. 4 By and For Women: Involving Women in the Development of Reproductive Health Care Materials, 1992. (E,S)

No. 5 Gente Joven/Young People: A Dialogue on Sexuality with Adolescents in Mexico, 1993. (E,S)

No. 6 The Coletivo: A Feminist Sexuality and Health Collective in Brazil, 1995. (E,P,S)

No. 7 Doing More with Less: The Marie Stopes Clinics of Sierra Leone, 1995. (E)

No. 8 Introducing Sexuality within Family Planning: Three Positive Experiences from Latin America and the Caribbean, 1997. (E,S)

No. 9 Using COPE to Improve Quality of Care: The Experience of the Family Planning Association of Kenya, 1998. (E,S)

No. 10 Alone You Are Nobody, Together We Float: The Manuela Ramos Movement, 2000. (E,S)

No. 11 From Patna to Paris: Providing Safe and Humane Abortion, 2001. (E)

No. 12 Universal Sexuality Education in Mongolia: Educating Today to Protect Tomorrow, 2002. (E)

No. 13 What about Us? Bringing Infertility into Reproductive Health Care, 2002. (E)

No. 14 "My Father Didn't Think This Way": Nigerian Boys Contemplate Gender Equality, 2003. (E,F)

No. 15 Linking Reproductive Health to Social Power: Community Health Workers in Belize and Pakistan, 2004. (E)

No. 16 Healing Wounds, Instilling Hope: The Tanzanian Partnership Against Obstetric Fistula, 2004. $(\mathrm{E}, \mathrm{F}, \mathrm{Sw})$ 
Quality/Calidad/Qualité, 